\title{
Lipid nanoparticles delivering constitutively active STING mRNA as a novel anti- cancer therapeutic approach
}

Wei Liu', Mohamad-Gabriel Alameh², June F. Yang ${ }^{1}$, Jonathan R. Xu', Paulo JC Lin ${ }^{3}$, Ying $\mathrm{K} \mathrm{Tam}^{3}$, Drew Weissman ${ }^{2}$, Jianxin You ${ }^{1 \#}$

${ }^{1}$ Department of Microbiology, Perelman School of Medicine, University of Pennsylvania, Philadelphia, PA 19104

${ }^{2}$ Division of Infectious Diseases, Perelman School of Medicine, University of Pennsylvania, Philadelphia, PA 19104

${ }^{3}$ Acuitas Therapeutics, Vancouver, BC, Canada

\#Corresponding author

Keywords: Lipid nanoparticles, constitutively active STING, mRNA, therapeutic approach, cancer 


\begin{abstract}
Treating immunosuppressive tumors represents a major challenge in cancer therapies. Activation of STING signaling has shown remarkable potential to invigorate the immunologically 'cold' tumor microenvironment (TME). However, we and others have shown that STING is silenced in many cancers, including pancreatic ductal adenocarcinoma (PDAC) and Merkel cell carcinoma (MCC), both of which are associated with an immune-dampened TME. In this study, we applied mRNA lipid nanoparticles (LNP) to deliver a permanently active gain-of-function STING ${ }^{\mathrm{R} 284 \mathrm{~S}}$ mutant into PDAC and MCC cells. Expression of STING ${ }^{\text {R284S }}$ induces cytokines and chemokines crucial for promoting intratumoral infiltration of $\mathrm{CD}^{+} \mathrm{T}$ cells and, importantly, also leads to robust cancer cell death while avoiding $\mathrm{T}$ cell entry and toxicity. Our studies demonstrated that mRNA-LNP delivery of STING ${ }^{R 284 S}$ could be explored as a novel therapeutic tool to reactivate antitumor response in an array of STING-deficient cancers while overcoming the toxicity and limitations of conventional STING agonists.
\end{abstract}

\title{
Introduction
}

Tumor immune suppression represents a major obstacle in achieving effective cancer immunotherapy. This is a clinical challenge present in many human malignancies, including pancreatic cancer. Pancreatic cancer causes the death of around 430,000 patients per year and persists as one of the deadliest malignancies in the world [1-4]. Few effective treatments are available for patients with advanced pancreatic cancer [5]. Nearly $98 \%$ of pancreatic cancer patients are also resistant to PD-1/PD-L1 immune checkpoint blockade therapies [6-9]. Thus, there is a significant unmet need for developing more effective therapies targeting this highly lethal cancer.

Pancreatic cancer often establishes a highly immunosuppressive tumor microenvironment (TME), which hinders retaliation by the host immune system and resists immunotherapies [2,10]. Therefore, cases of this cancer are traditionally classified as non-immunogenic "cold" tumors $[2,10,11]$. Typically, tumor-infiltrating CD8 ${ }^{+}$ cytotoxic $\mathrm{T}$ cells are strongly associated with patient survival. However, the majority of pancreatic cancers lack successful infiltration of effective CD8 ${ }^{+} \mathrm{T}$ cells in the TME [1113]. Poor intratumoral $T$ cell infiltration and activation present a major hurdle for developing effective immunotherapies, revealing the need for novel therapeutic strategies.

In our previous studies, we discovered that repression of Stimulator of interferon genes (STING) is a key factor underpinning the immunologically "cold" TME of Merkel cell carcinoma (MCC) [14], which is another highly aggressive cancer with over $30 \%$ of patients showing metastatic disease at first presentation $[15,16]$. STING is a key regulator of innate immune signaling and antitumor responses [17-20]. The canonical role of the STING signaling pathway is to sense cytoplasmic double-stranded DNA (dsDNA) including host cytoplasmatic chromatin, mitochondrial DNA, and foreign dsDNA such as viral dsDNA. These DNA molecules are recognized by cyclic GMP-AMP synthase (cGAS), which in turn synthesizes 2'3'-cGAMP that can bind to and activate STING. After stimulation by pathogen- or damage-associated molecular patterns (PAMPs or DAMPs), STING activates the transcription of type I and III interferons 
(IFNs) and other pro-inflammatory cytokines to initiate the innate immune response [2124]. Cancer cells often maintain abundant damaged DNA, which can also stimulate STING-dependent induction of IFNs and several other anti-tumor cytokines/chemokines including CXCL10 and CCL5 [17,20-23]. Among the molecules activated by STING signaling, IFNs can stimulate the generation of anti-tumor $\mathrm{T}$ cells, T-cell infiltration, and the direct killing of cancer cells [25-27], whereas CXCL10 and CCL5 are important for recruiting tumor-reactive effector $T$ cells [17-20,28-30]. Therefore, activation of the STING signaling pathway has demonstrated great promise to trigger a switch in the TME of tumors from an immune suppressed 'cold' environment to an immune activated 'hot' environment [14,17-20,29-36].

We recently discovered that STING is silenced in MCC and that reactivating STING stimulates antitumor inflammatory cytokine/chemokine production, cytotoxic T cell infiltration and activation, and eradication of MCC cells [14]. Our studies in MCC provide proof-of-principle data to support the hypothesis that targeted reactivation of STING can bolster antitumor cytotoxicity and invigorate the immune-dampened TME in STING-silenced and immunologically 'cold' tumors. We also found that STING is silenced or downregulated in a number of other types of cancers, such as pancreatic ductal adenocarcinoma (PDAC) [14]. In this study, we set out to develop new strategies to reactivate STING signaling in order to bolster antitumor immunity and enforce tumor immunogenicity in STING-silenced PDAC cancer.

In light of the recent findings on the antitumor functions of the cGAS-STING pathway, several STING agonists have been developed to stimulate anti-tumor immune responses, including the activation of $\mathrm{CD}^{+} \mathrm{T}$-cells and natural killer cells, and to induce tumor regression in multiple mouse tumor models [19,32,36-38]. However, clinical trials of these STING agonists did not show beneficial results $[39,40]$. The contradicting outcomes between mouse tumor models and human clinical trials might be associated with the distinct levels of STING gene expression in these different tumors. While STING is highly expressed in many mouse tumor cell lines, such as CT26 [41] and B16F10 [42], it is silenced in several human cancers as demonstrated in studies from our group and others $[14,20,43]$. It has also been shown that B16-F10 STING knockout cells were more resistant to immunotherapy [42]. Thus, although STING has been shown to be a promising target for cancer therapies, STING agonists might be of little benefit in STING-deficient tumors.

To overcome the limitations of traditional STING agonists, which do not work in STING-silenced cancers [36,44,45], we explored the idea of introducing naturally occurring constitutively active gain-of-function STING mutants [46,47] into STINGsilenced immunologically "cold" PDAC to reactivate antitumor immunity. STING gain-offunction mutations have emerged in multiple systemic autoinflammatory diseases, including STING-associated vasculopathy with onset in infancy, systemic lupus erythematosus-like syndromes, and familial chilblain lupus diseases [46-61]. These mutations support constitutively hyperactive STING activity, which induces an excessive IFN response that attracts and amasses proinflammatory cells to cause autoimmune disease symptoms [46-51,54,56-60]. We therefore hypothesized that these gain-offunction STING ('hot' STING) mutants could be leveraged to activate the STING 
signaling pathway for treating STING-deficient cancers. In this study, we explored the idea of harnessing these permanently active 'hot' STING mutants to 'heat up' STINGdeficient immunologically 'cold' cancers.

We first discovered that the expression of the STING ${ }^{\text {R284S }}$ mutant in PDAC cells robustly activates the STING signaling pathway. To further develop a 'hot' STING cancer therapy, we generated lipid nanoparticles (LNP) to deliver STING ${ }^{\text {R284S }}$ mRNA into cells. We observed that the LNP-delivered STING ${ }^{\text {R284S }}$ mRNA could vigorously reactivate anti-tumor cytokine production and induce cancer cell death in STINGsilenced PDAC and MCC cells. Moreover, because T cells are intrinsically resistant to exogenous mRNA delivery by LNP, STING ${ }^{\text {R284S }}$ mRNA-LNP do not introduce $T$ cell cytotoxicity, which could normally be induced by traditional STING agonists. Our results suggest that STING ${ }^{\text {R284S }}$ mRNA-LNP can overcome the toxicity and limitations of conventional STING agonists and therefore could be exploited as a new therapeutic approach for treating an array of STING-deficient cancers that are refractory to current therapies.

\section{Results}

\section{STING is downregulated in some PDAC lesions}

We recently discovered that STING expression is absent in MCC and several other cancer cells, including a number of PDAC cell lines [14]. Following up on that study, we analyzed the STING protein levels in several PDAC cell lines and patient lesions (Fig. 1). From the cell line analysis, we found that STING protein is scarce in AsPC-1, PANC-1, and Capan-1 cells, and virtually undetectable in MIA PaCa-2, as compared with primary human dermal fibroblasts (HDFs). In contrast, the levels of cyclic GMP-AMP synthase (cGAS), the upstream activator of STING, are clearly detected in all the tested cell lines (Fig.1A). To confirm these observations, we co-stained STING protein and the PDAC marker CK19 [62] to examine the STING protein level in PDAC tumor lesions. STING was nearly untraceable in three out of the seven lesions, including those from patients \#1780, \#4476, and \#4021. An interesting observation was made for the lesions isolated from patients \#T5_1589 and \#3917: while STING signal was detected in CK19- cells, it was found to be specifically silenced in $\mathrm{CK}^{-} 19^{+}$cells (Fig.1B). The rest of the PDAC lesions, from patient \#3791 and patient \#1832, indicate normal STING protein level (Fig.1B). These results demonstrate that STING expression could be silenced or repressed in certain PDACs and there appeared to be a pattern of tumor cell-specific repression in some PDAC lesions. Our finding suggests that STING downregulation may contribute to the immunologically 'cold' TME in some PDACs.

\section{Identification of a highly active STING gain-of-function mutant}

We then set out to establish a new approach for reactivating the STING signaling pathway in STING-silenced cancers using STING gain-of-function genetic mutants. Several single amino acid STING gain-of-function mutants have been identified in autoinflammatory diseases. Among these, the STING ${ }^{\mathrm{V} 147 \mathrm{~L}}$, STING ${ }^{\mathrm{N} 154 \mathrm{~S}}$, STING ${ }^{\mathrm{V} 155 \mathrm{M}}$, and STING ${ }^{\text {R284S }}$ mutants have demonstrated high activity in stimulating downstream innate immune signaling $[46,47,60]$. Thus, they offer an exciting opportunity to create a 
simple approach to reactivate the STING signaling pathway. We therefore tested whether these gain-of-function mutants could be used to reignite the anti-tumor activities of the STING signaling pathway in cancer cells. To screen the capability of these STING gain-of-function mutants to inhibit tumor proliferation, we constructed MIA PaCa-2 cells stably expressing either doxycycline (dox)-inducible wild type (WT) STING or one of the STING mutants. Expression of the STING ${ }^{\text {R284S }}$ mutant in MIA PaCa-2 cells significantly increased the expression of the early cell death marker cleaved caspase-3 (Fig. 2A) and also inhibited cell proliferation, likely by escalating the number of cells going through cell death (Fig. 2B). In contrast, expression of STING ${ }^{\mathrm{WT}}$ and the other STING gain-of-function mutants did not induce such an effect. Notably, all the STING gain-of-function mutants showed lower signal than WT STING (Fig. 2A). This is consistent with previous studies showing that activated STING proteins are quickly degraded [63-65]. Based on the result of this experiment, we selected the STING ${ }^{\text {R284S }}$ mutant for our further studies.

\section{Ectopic expression of dox-inducible STING ${ }^{\mathrm{R} 284 S}$ induces key anti-tumor cytokine production and cell death in PDAC cells}

Our previous study showed that reactivation of the STING signaling pathway not only induces cell death but also generates robust expression of anti-tumor cytokines, such as IFNs, CXCL10, CCL5, and IL6 [14]. To examine whether the STING ${ }^{\text {R284S }}$ mutant has the same downstream function, we constructed PDAC cell lines MIA PaCa2 and BxPC-3 stably expressing dox-inducible STING ${ }^{\mathrm{WT}}$ or STING ${ }^{\mathrm{R} 284 \mathrm{~S}}$. STING expression was efficiently induced by dox treatment in both stable cell lines (Fig. 3A-B, Fig. S1A-B). Compared to STING ${ }^{W T}$, dox-induced STING ${ }^{R 284 S}$ stimulated the expression of STING downstream anti-tumor cytokines, such as CCL5, CXCL10, IL29, IL6, IFN $\beta$ and TNF $\alpha$ (Fig.3C, Fig. S1C). Moreover, compared to un-induced cells and cells expressing dox-induced STING ${ }^{W T}$, expression of STING ${ }^{R 284 S}$ increased the level of cleaved caspase-3 (Fig. 3A, Fig.S1A) and drastically inhibited the proliferation of these cancer cells (Fig. 3D, Fig. S1D). These results demonstrate that the STING ${ }^{\text {R284S }}$ mutant can provoke key anti-tumor cytokine production and cause widespread PDAC cancer cell death. In the in vivo setting, tumor cells killed by STING ${ }^{\text {R284 }}$ expression could release significant quantities of tumor antigens as well as DNA to activate $T$ cells and amplify both innate and adaptive antitumor responses [66]. Our findings therefore indicate that introducing STING ${ }^{\mathrm{R} 284 \mathrm{~S}}$ into tumor cells may be a viable therapeutic strategy for treating STING-deficient cancers.

\section{A novel approach to reactivate the STING signaling pathway}

We faced a challenge when designing a strategy to deliver the STING ${ }^{\mathrm{R} 284 S}$ mutant into tumor cells as an anticancer therapeutic agent. Viral vectors cannot be used to carry the 'hot' STING ${ }^{\mathrm{R} 284}$ mutant because activation of the STING signaling pathway blocks packaging of many viral-derived vectors $[64,67,68]$. On the other hand, mRNALNP has emerged as a powerful tool for delivering gene expression in cancer cells [69] and also as strong T Helper 1 (Th1) biased adjuvants [70]. Importantly, nucleosidemodified mRNA-LNP can quickly produce abundant protein in target cells while avoiding the host innate immune response [70-81]. Moreover, LNP can be used to package the 'hot' STING ${ }^{\mathrm{R} 284}$ mutant mRNA in vitro without activation of the host STING signaling 
pathway $[71,82]$. As a first step to test this strategy, we generated mRNAs encoding STING ${ }^{\text {2284S }}$ and STING ${ }^{\mathrm{WT}}$ and transfected them into PDAC cells. Compared to mocktransfected cells, robust STING expression was detected in STING ${ }^{\mathrm{WT}}$ and STING ${ }^{\mathrm{R} 284 S}$ mRNA-transfected PDAC cells (Fig. 4A-B, Fig. S2A-B). However, only STING ${ }^{\text {2284S }}$ mRNA, not STING ${ }^{W T}$ mRNA, stimulated the production of anti-tumor cytokines, such as CCL5, CXCL10, IL29, IL6, IFN $\beta$, and TNF $\alpha$ (Fig. 4C, Fig. S2C). In addition, unlike STING ${ }^{W T}$ mRNA, transfection of STING ${ }^{R 284 S}$ mRNA significantly elevated the level of cleaved caspase-3 and reduced the cancer cell proliferation rate appreciably (Figs. 4A, 4D, S2A, S2D). These results show that transfection with STING ${ }^{R 24 S}$ mRNA can specifically stimulate the STING signaling pathway to produce essential anti-tumor cytokines and kill cancer cells.

\section{STING ${ }^{\text {R284S }}$ expression delivered by mRNA-LNP activates vital anti-tumor cytokines and induces PDAC cell death}

To further develop a therapeutic approach, we tested whether LNP can be used to deliver the STING ${ }^{\text {2284S }}$ mRNA into cancer cells. The LNP we exploited in this study have been shown to efficiently deliver genes in vivo [83]. However, we did not observe significant expression of STING ${ }^{\mathrm{WT}}$ and STING ${ }^{\mathrm{R} 284 \mathrm{~S}}$ in MIA PaCa-2 and BxPC-3 cells treated with the respective mRNA-LNP (Figs. 5A and S3A, rows 2, 5). We reasoned that this could be due to a lack of Human Apolipoprotein E (APOE) in our in vitro cultures. In the in vivo setting, APOE plays an important role in the cellular uptake of physiological lipoproteins through binding to low-density lipoprotein (LDL) receptors [84,85]. When mixed with mRNA-LNP before transduction, human APOE4 has been shown to radically increase mRNA-LNP transduction efficiency in vitro $[84,85]$. We therefore tested whether mixing STING ${ }^{W T}$ or STING ${ }^{R 285}$ mRNA-LNP with APOE4 could facilitate the delivery of mRNA into PDAC cells. We found that APOE4 robustly stimulates the delivery of mRNA-LNP into PDAC cells in a dose-dependent manner (Fig. 5A, Fig. S3A). Compared to untreated cells, higher levels of STING ${ }^{\mathrm{WT}}$ and STING ${ }^{\mathrm{R} 284 \mathrm{~S}}$ mRNA were detected by RT-PCR in cells treated with a combination of mRNA-LNP and APOE4 (Fig. 5B, Fig. S3B). The combined treatment of STING ${ }^{\text {R284S }}$ mRNA-LNP and APOE4 also significantly augmented the expression of key anti-tumor cytokines, such as CCL5, CXCL10, IL29, IL6, and TNF $\alpha$, as compared with treatment using only STING ${ }^{\text {WT }}$ mRNA (Fig.5C, Fig. S3C). Moreover, LNP-delivered STING ${ }^{\text {R284S }}$ mRNA not only induced the production of cleaved caspase-3 in PDAC cells, but also significantly inhibited the proliferation of these cells (Figs. 5A, 5D, S3A, S3D). Importantly, the same treatment did not repress the proliferation of CD8+ T cells (Fig. S3E) (see discussion). These results demonstrate that human APOE4 can efficiently promote the delivery of mRNA-LNP into target cells, allowing the robust expression of 'hot' STING R284S to induce essential anti-tumor cytokines and eradicate cancer cells.

\section{STING ${ }^{\text {R284S }}$ mRNA-LNP also trigger vital anti-tumor cytokine production and cell death in MCC cells}

We recently found that STING is also silenced in some MCC tumors [14]. 80\% of MCCs have integrated Merkel cell polyomavirus (MCPyV) genomes [86]. Our previous studies showed that STING is specifically repressed in MCPyV ${ }^{+}$MCC cell lines [14]. By analyzing published RNA-seq data [87], we discovered that while STING is amply 
expressed in the MCPyV ${ }^{-}$MCC cell line UISO, STING RNA expression levels are nearly undetectable in all six classic $\mathrm{MCPyV}^{+} \mathrm{MCC}$ cell lines: MKL-1, MKL-2, MS-1, WaGa, PeTa, and BroLi (Fig.S4A). The RNA-seq data also indicated that when compared with other $\mathrm{MCPyV}^{+} \mathrm{MCC}$ cell lines, STING RNA expression is slightly higher in PeTa cells (Fig.S4A) [87]. However, Western-blot analysis reveals that, similar to MKL-1 cells, STING protein expression in PeTa cells is completely imperceptible (Fig. S4B). This study therefore confirmed that STING expression is suppressed in all of the classic $\mathrm{MCPyV}^{+} \mathrm{MCC}$ cell lines we have examined.

Encouraged by the observed antitumor activity of the STING ${ }^{R 284 S}$ mRNA-LNP in PDAC cells, we tested whether our LNP approach could be applied to stimulate the same positive response in MCC cells. We first optimized the mRNA-LNP delivery conditions for MCC cells using firefly luciferase mRNA-LNP. We ascertained that 10 $\mathrm{ug} / \mathrm{ml}$ of human APOE4 was also the ideal concentration for delivering mRNA-LNP into MCC cells (Fig. S5). When compared with the untreated MKL-1 and MS-1 MCC cells, robust STING expression was detected in both STING ${ }^{\mathrm{WT}}$ and STING ${ }^{\mathrm{R} 284 \mathrm{~S}}$ mRNA-LNPtreated cells (Figs. 6A-B, S6A-B). However, only delivery of STING ${ }^{\text {R284S }}$ mRNA-LNP, and not STING ${ }^{\mathrm{WT}}$ mRNA-LNP, stimulated expression of the key anti-tumor cytokines CCL5, CXCL10, IL29, IL6, IFN $\beta$, and TNF $\alpha$ (Figs. 6C, S6C). Compared to STING ${ }^{\mathrm{WT}}$ mRNA-LNP, treating MCC cells with STING ${ }^{R 284}$ mRNA-LNP also elevated the level of cleaved caspase-3 and greatly inhibited cell proliferation (Figs. 6A, 6D, S6A, S6D). These results demonstrated that the STING ${ }^{R 284 S}$ mRNA-LNP could also induce antitumor cytokine expression and cell death in tested MCC cell lines.

In summary, we demonstrated that STING ${ }^{R 284 S}$ mRNA-LNP robustly activate the STING signaling pathway in cancer cells, leading to the production of key anti-tumor cytokines as well as cancer cell death. Therefore, STING ${ }^{\text {R284S }}$ mRNA-LNP could be exploited as a promising anticancer drug for treating STING-deficient cancers.

\section{Discussion}

Currently, several therapeutic approaches such as PD-1/PD-L1 and CTLA-4 inhibitors have been appraised in attempts to combat aggressive cancers such as PDACs and MCCs, but have failed to produce durable responses in PDACs [88] and led to treatment resistance in some MCCs [89]. Therefore, alternative therapeutics are still needed for treating these lethal cancers.

The complex tumor microenvironment presents a major barrier to developing broadly effective therapies. The TME of PDAC is known to be immunosuppressive. Although tumor infiltration of $\mathrm{T}$ lymphocytes was positively correlated with overall patient survival [90], the PDAC TME has very few tumor-infiltrating CD8+ cytotoxic T cells and CD4+ T helper cells, and instead exhibits an increased presence of regulatory $T$ cells, tumor-associated macrophages, and myeloid-derived suppressor cells [91,92]. We and others have reported that the STING signaling pathway is dysfunctional in several cancers $[14,20,43]$. Thus, we examined the expression of key components of this pathway, cGAS and STING, in PDAC cell lines. We found that all tested pancreatic cancer cell lines maintain highly expressed cGAS, but STING is significantly downregulated in many of the PDAC cell lines and tissues (Fig. 1). In light of the STING function in stimulating antitumor response, we speculated that STING repression might 
contribute to the immunosuppressive TME of PDACs and that reactivating STING might represent a viable strategy for heating up the immunologically 'cold' TME in PDAC.

To stimulate STING activity in PDAC cells, we first screened several 'hot' STING mutants. We discovered that only the STING ${ }^{R 284 S}$ mutant, but not STING ${ }^{W T}$ nor the other STING gain-of-function mutants such as STING ${ }^{\mathrm{V} 147 \mathrm{~L}}$, STING ${ }^{\mathrm{N} 154 \mathrm{~S}}$, and STING ${ }^{\mathrm{V} 155 \mathrm{M}}$, could specifically inhibit the growth of STING-silenced MIA PaCa-2 cells (Fig. 2). The result correlates appropriately with the clinical impact of these gain-offunction mutations. For example, the STING ${ }^{\mathrm{V} 147 \mathrm{~L}}$, STING ${ }^{\mathrm{N} 154 \mathrm{~S}}$ and STING ${ }^{\mathrm{V} 155 \mathrm{M}}$ mutants were identified in patients who died at an age of at least 9 years [49], but the STING ${ }^{\text {R284S }}$ mutant was derived from a patient who died at approximately 9 months of age [47]. Together, our finding suggests that, among all of the mutants tested, STING ${ }^{R 284 S}$ has the highest activity in stimulating the STING signaling pathway. This discovery provides the molecular basis for using the STING ${ }^{\text {R284S }}$ mutant to develop STING-targeted immunotherapies.

Our further studies demonstrated that STING ${ }^{\text {R284S }}$ mRNA-LNP could be efficiently delivered into PDAC cells to induce cytokines/chemokines crucial for promoting intratumoral infiltration of $\mathrm{CD}^{+} \mathrm{T}^{\mathrm{T}}$ cells. More importantly, STING ${ }^{\mathrm{R} 284 \mathrm{~S}}$ expression also induces robust cell death in STING-silenced cancers (Figs. 5 and S3). MCCs also have an immunologically 'cold' TME and STING is invariably repressed in the $\mathrm{MCPyV}^{+} \mathrm{MCC}$ tumors we have examined. We further demonstrated that STING ${ }^{\text {R284S }}$ mRNA-LNP could also be utilized to activate STING downstream antitumor activity in MCC tumor cells. In summary, by harnessing the hyperactive immune-stimulatory activity of the STING ${ }^{\text {284S }}$ mutant and the delivery capability of mRNA-LNP, we have provided evidence for using the naturally occurring STING ${ }^{R 24 S}$ mutant as a novel therapeutic tool to reactivate the antitumor response in the immunologically 'cold' pancreatic cancer and in other STINGsilenced tumors.

Several observations suggest that STING ${ }^{R 284 S}$ mRNA-LNP hold great promise for developing a cancer immunotherapy. First, when compared with wild type STING, 'hot' STING mutants such as STING ${ }^{\text {R284S }}$ are more responsive to cGAMP [46,47,49,51]. When delivered into tumor cells by mRNA-LNP, STING ${ }^{R 24 S}$ can be further activated by the large amount of damaged DNA present in these cells, spurring robust antitumoral activity. Therefore, no additional STING agonist is needed to stimulate 'hot' STING mutants, increasing the feasibility for clinical application. Secondly, pancreatic cancers possess few tumor-specific new epitopes (neoantigens) [12]. STING ${ }^{\text {2284S }}$ mRNA-LNPinduced cell death will play a crucial role in exposing neoantigens of tumors to the host immune system. The large amount of tumor antigens released by the dead cells can be engulfed by antigen-presenting cells (APCs) and presented to $T$ cells to generate systemic antitumor immunity and amplify the tumoricidal effect. This process could also induce adaptive antitumor immunity for rejecting distant metastases and providing longliving immunologic memory. Thirdly, STING ${ }^{\mathrm{R} 284 \mathrm{~S}}$-mediated cell death can also directly reduce cancer burden, which is also clearly beneficial to cancer immunotherapy [93,94]. Finally, mRNA-LNP has an intrinsic adjuvant effect that can stimulate $T$ follicular helper cells (Tfh) responses and promote the production of effective CD8 ${ }^{+} \mathrm{T}$ cells $[70,78,95]$. An additional advantage is that multiple mRNAs can be combined together or with other drugs to be encapsidated into LNP $[78-81,96]$. 
The STING ${ }^{\text {R284S }}$ mRNA-LNP approach can be used to restore STING expression and function in STING-deficient tumors in order to stimulate anti-tumor immune responses and directly kill the tumor cells (Figs 4C, 5C, S3C, and S5C). Anti-tumor cytokines have safety concerns when systemically administered; however, gene expression driven by intratumorally-injected mRNA-LNP has been detected mainly in the tumor sites but not in major vital organs [96,97]. Therefore, local delivery using STING ${ }^{\text {R284S }}$ mRNA formulated in LNP could overcome the specificity issue and reveal a safe approach to leverage the cytokine effects [98,99]. Additionally, overstimulation of STING in T cells could introduce cell death and cytotoxicity, which counteracts the desired antitumor immune response [17,55,100-103]. Interestingly, we found that while STING ${ }^{\text {R284S }}$ mRNA-LNP can effectively repress cancer cell proliferation, it does not inhibit the growth of $\mathrm{CD}^{+} \mathrm{T}$ cells (Figs. 4D, 5D, S3D, S5D and S3E). This is consistent with previous studies confirming that $T$ cells are not susceptible to transfection by exogenous mRNA delivered in LNP [104]. Therefore, mRNA-LNP-mediated intratumoral delivery of STING ${ }^{\text {R284S }}$ will allow specific activation of STING signaling in tumor tissues without introducing antiproliferative effects in lymphocytic immune cells. Because mRNA-LNP delivery is transient, it also allows for greater control of the treatment process. So far, all STING ${ }^{R 284 S}$ mRNA-LNP studies were performed in vitro. Plans are underway to establish STING-negative tumor models in mice, which will be used to examine the efficacy of the STING ${ }^{R 284}$ mRNA-LNP in stimulating T cell intratumoral infiltration and killing of tumor cells in vivo. Furthermore, we are also developing specific targeting strategies in order to apply the STING ${ }^{\mathrm{R} 284 \mathrm{~S}}$ mRNA-LNP for treating metastatic disease.

STING agonists are being actively pursued as new cancer immunotherapies $[36,44,45,105]$, but few have generated positive clinical outcome $[39,40]$. As shown by our group and others, STING is silenced in many cancers [14,20,43]. Our findings could explain why traditional STING agonists will not work in STING-silenced cancers, as the antitumor efficacy of these agonists obligatorily depends on STING expression to begin with [44]. When delivered into noncancerous cells, the classic STING agonists can also induce inflammatory diseases and cancers $[17,103]$. Our STING ${ }^{R 284 S}$ mRNA-LNP approach therefore represents a novel therapeutic strategy that can overcome the limitations and toxicity of conventional STING agonist-based therapies. It also possesses broader potential for overcoming the immunosuppressive microenvironment in other STING-deficient 'cold' tumors.

\section{Materials and methods}

\section{Cell culture and cancer lesions}

Primary foreskin dermal fibroblasts [106], human embryonic kidney 293T (HEK293T), MIA PaCa-2, and PANC-1 cells were grown in Dulbecco's modified Eagle's medium supplemented with $10 \%$ fetal calf serum. BxPC-3 and AsPC-1 cells were grown in RPMI 1640 medium supplemented with 10\% fetal calf serum. Capan-1 and Capan-2 cells were grown in McCoy's 5A Medium supplemented with $10 \%$ fetal calf serum. MKL1 and MS-1 cells were grown in RPMI 1640 medium supplemented with $20 \%$ fetal calf serum. All the cells were incubated at $37^{\circ} \mathrm{C}$ in humidified air containing $5 \% \mathrm{CO} 2$. Primary $\mathrm{CD}^{+} \mathrm{T}$ cells from healthy donors were provided by the Human Immunology 
Core at the University of Pennsylvania. These cells were grown in RPMI 1640 medium supplemented with 10\% heat-inactivated FBS, L-glutamine, IL-2 and PenicillinStreptomycin. PDAC tissues were obtained from the Tumor Tissue and Biospecimen Bank at the University of Pennsylvania.

\section{Western blot analysis}

To prepare whole cell lysates, cells were lysed in lysis buffer (10 mM HEPES, pH 7.9, $500 \mathrm{mM} \mathrm{NaCl}, 3 \mathrm{mM} \mathrm{MgCl}$, $1 \mathrm{mM}$ DTT, $1 \mathrm{mM}$ PMSF, 0.5\% Triton X-100 supplemented with protease inhibitors). After 30 minutes of incubation on ice, whole cell lysates were centrifuged at $15,000 \mathrm{~g}$ for $10 \mathrm{~min}$ at $4^{\circ} \mathrm{C}$ to remove the debris. Protein concentrations were determined using the Bradford assay. The protein samples were resolved on SDS-PAGE gels, transferred onto PVDF membranes, and immunoblotted with specific primary antibodies as indicated in the figure legends. The primary antibodies used in this study include anti-STING (1:2000, 13647S, Cell Signaling Technology), anti-cGAS (1:1000, 15102, Cell Signaling Technology), and anti-GAPDH (1:2000, 5174S, Cell Signaling Technology). The secondary antibody used was HRPlinked anti-rabbit IgG (1:3000, 7074S, Cell Signaling Technology). Western blots were developed using SuperSignal ${ }^{\mathrm{TM}}$ West Pico PLUS Chemiluminescent Substrate (Thermo Scientific) and images were captured using a GE imaging system.

\section{Cell proliferation assay}

Cell viability was measured with CellTiter-Glo 3D (Promega) following the manufacturer's instructions [107].

\section{Reverse transcription and quantitative real-time PCR}

Total RNA was isolated using NucleoSpin RNA II Kit (Macherey-Nagel) in pursuance of the manufacturer's protocol. Reverse transcription (RT) was performed using a $20 \mu \mathrm{l}$ reaction mixture containing $350 \mathrm{ng}$ of total RNA, random hexamer primers (Invitrogen), dNTPs (Invitrogen), and M-MLV reverse transcriptase (Invitrogen). Quantitative real-time PCR (qPCR) was performed using a CFX96 real-time PCR detection system (Bio-Rad) with IQ SYBR Green supermix (Bio-Rad). Primer sequences are the same as listed in [14]. The mRNA level of each gene was normalized to the GAPDH mRNA level.

\section{Immunofluorescent staining}

Cells were fixed with $3 \%$ paraformaldehyde in PBS for 20 minutes. Immunofluorescent (IF) staining was performed as previously described [108]. The following primary antibodies were used: anti-CK19 (1:200, 4558, Cell Signaling Technology), anti-STING (1:500 for cell staining, 1:20 for tissue staining, 19851-1-AP, Proteintech), and anti-Cleaved Caspase-3 (Asp175) (1:500, 9661, Cell Signaling Technology). The secondary antibodies used were Alexa Fluor 594 goat anti-mouse $\lg$ (1:500, A-11032, ThermoFisher Scientific) and Alexa Fluor 488 goat anti-rabbit IgG (1:500, A-11008, ThermoFisher Scientific). All IF images were collected using an inverted fluorescence microscope (IX81; Olympus) connected to a high-resolution charge-coupled-device camera (FAST1394; QImaging). Images were analyzed and 
presented using SlideBook (version 5.0) software (Intelligent Imaging Innovations, Inc.). The scale bars were added using ImageJ software.

\section{Recombinant plasmid construction}

PTEV-STING ${ }^{W T}-A 101$ plasmid containing codon-optimized STING ${ }^{W T}$ gene was synthesized by Genewiz. pTEV-STING ${ }^{\text {R284S }}-A 101$ plasmid containing the STING ${ }^{\text {R284S }}$ gene was generated from codon-optimized human STING ${ }^{\mathrm{WT}}$ by PCR-based sitedirected mutagenesis.

\section{mRNA production}

Using linearized plasmid pTEV-STING ${ }^{W T}-A 101$ and pTEV-STING ${ }^{\text {R284S }}-A 101$, the STING mRNA was produced with T7 RNA polymerase. During mRNA synthesis, 1methylpseudouridine-5'-triphosphate (TriLink) was used instead of UTP to generate modified nucleoside-containing mRNA. The STING mRNA was co-transcriptionally capped using CleanCap (TriLink) and purified as described previously [70]. The STING mRNA was analyzed by agarose gel electrophoresis and stored frozen at $-80^{\circ} \mathrm{C}$.

\section{mRNA transfection}

Transfection of human pancreatic MIA PaCa-2 and BxPC-3 cells was performed with TransIT-mRNA (Mirus Bio) according to the manufacturer's instructions. Specifically, mRNA $(1 \mu \mathrm{g})$ was combined with TranslT-mRNA reagent $(3 \mu \mathrm{l})$ and boost reagent $(3 \mu \mathrm{l})$ in $100 \mu \mathrm{l}$ of serum-free medium, and the complex was added to $10 \mathrm{e}^{5}$ cells in $500 \mu \mathrm{l}$ complete medium. Cells were harvested at 15-16 h after transfection.

\section{LNP encapsulation of the mRNA}

Purified STING mRNAs were encapsulated in LNP using a self-assembly process in which an aqueous solution of mRNA at $\mathrm{pH} 4.0$ is rapidly mixed with a solution of lipids dissolved in ethanol. LNP used in this study were similar in composition to those described previously [71], which contain an ionizable cationic lipid (proprietary to Acuitas), phosphatidylcholine, cholesterol and PEG-lipid. The ionizable cationic lipid and LNP composition are described in the patent application WO 2017/004143. The diameter and polydispersity index of LNP was measured by dynamic light scattering using a Zetasizer Nano ZS instrument (Malvern Instruments Ltd) and an encapsulation efficiency of $\sim 95 \%$ as determined using a Ribogreen assay. RNA-LNP formulations were stored at $-80^{\circ} \mathrm{C}$ at an RNA concentration of $\sim 1 \mu \mathrm{g} / \mu \mathrm{l}$.

\section{Mutagenesis Primers}

The sequences for the primers used in STING mutagenesis are:

STING ${ }^{\mathrm{V} 155 \mathrm{M}} \mathrm{F}$ : AACATGGCCCATGGGCTGGCATGG

STING ${ }^{\mathrm{N} 154 \mathrm{~S}} \mathrm{~F}:$ AGCGTGGCCCATGGGCTGGCATGG

STING ${ }^{\mathrm{N} 154 \mathrm{~S}} \mathrm{R}$ : GAAATTCCCTTTTTCACACACTGCAGAG

STING ${ }^{\mathrm{V} 147 \mathrm{~L}_{\mathrm{F}}:}$ : CTGTGTGAAAAAGGGAATTTCAACGTGG

STING ${ }^{\mathrm{V} 147 \mathrm{~L}} \mathrm{R}:$ TGCAGAGATCTCAGCTGGGG

\section{Statistical analyses}


Statistical analysis was performed using the unpaired t-test of GraphPad Prism software (Version 7.0) to compare the data from the control and experimental groups. A two-tailed $P$ value of $<0.05$ was considered statistically significant.

Funding: This work has been supported by NIH Grants R01CA187718, R21AR074073, R21Al149761, T32CA009140, National Cancer Institute Cancer Center Support Grant NCI P30 CA016520, and Penn Center for AIDS Research Pilot Award P30 Al 045008.

Acknowledgments: We thank the Human Immunology Core (University of Pennsylvania) through Grants P30-CA016520 and P30Al045008 for providing purified human $\mathrm{CD}^{+} \mathrm{T}$ cells; Dr. Erle S. Robertson (University of Pennsylvania) for pancreatic cancer cell lines MIA PaCa-2, BxPC-3, PANC-1, AsPC-1, Capan-1, and Capan-2; the Tumor Tissue and Biospecimen Bank (University of Pennsylvania) for providing PDAC tissues; Dr. Dominic De Nardo (Monash University) for pTRIPZ-STING ${ }^{\mathrm{WT}}$ and pTRIPZ-STING ${ }^{\text {R284S }}$ plasmids; and Drs. Ben Stanger and Ranran Wang for helpful discussion.

Author Contributions: Wei Liu: conceptualization, formal analysis, investigation, methodology, visualization, writing - original draft, writing- review \& editing; MohamadGabriel Alameh: resources, writing- review \& editing; June F. Yang: methodology, writing - original draft, writing- review \& editing; Jonathan R. Xu: literature research, conceptualization, writing- review \& editing; Paulo JC Lin: resources, writing- review \& editing; Ying K Tam: resources, writing- review \& editing; Drew Weissman: supervision, resources, writing- review \& editing; Jianxin You: conceptualization, funding acquisition, project administration, supervision, writing- original draft, writing- review \& editing.

Conflicts of Interest: The authors declare no conflict of interest

\section{References}

1. Rawla, P.; Sunkara, T.; Gaduputi, V. Epidemiology of pancreatic cancer: Global trends, etiology and risk factors. World Journal of Oncology 2019, 10, 10-27.

2. Looi, C.-K.; Chung, F.F.-L.; Leong, C.-O.; Wong, S.-F.; Rosli, R.; Mai, C.-W. Therapeutic challenges and current immunomodulatory strategies in targeting the immunosuppressive pancreatic tumor microenvironment. Journal of Experimental \& Clinical Cancer Research 2019, 38, 162.

3. Karamitopoulou, E. Tumour microenvironment of pancreatic cancer: Immune landscape is dictated by molecular and histopathological features. British Journal of Cancer 2019, 121, 5-14.

4. Aiello, N.M.; Rhim, A.D.; Stanger, B.Z. Orthotopic injection of pancreatic cancer cells. Cold Spring Harbor Protocols 2016, 2016, pdb.prot078360.

5. Adel, N. Current treatment landscape and emerging therapies for pancreatic cancer. The American Journal of Managed Care 2019, 25, S3-s10.

6. $\quad$ Feng, M.; Xiong, G.; Cao, Z.; Yang, G.; Zheng, S.; Song, X.; You, L.; Zheng, L.; Zhang, T.; Zhao, Y. PD-1/PD-L1 and immunotherapy for pancreatic cancer. Cancer Letters 2017, 407, 57-65. 
7. Soares, K.C.; Rucki, A.A.; Wu, A.A.; Olino, K.; Xiao, Q.; Chai, Y.; Wamwea, A.; Bigelow, E.; Lutz, E.; Liu, L., et al. PD-1/PD-L1 blockade together with vaccine therapy facilitates effector T-cell infiltration into pancreatic tumors. Journal of Immunotherapy (Hagerstown, Md. : 1997) 2015, 38, 1-11.

8. Lu, C.; Liu, K. Epigenetic regulation of PD-L1 expression and pancreatic cancer response to checkpoint immunotherapy. Translational Cancer Research 2017, 6, S652-s654.

9. Hay, C.A.; Sor, R.; Flowers, A.J.; Clendenin, C.; Byrne, K.T. Ultrasound-guided orthotopic implantation of murine pancreatic ductal adenocarcinoma. Journal of Visualized Experiments : JoVE 2019.

10. Chang, J.H.; Jiang, Y.; Pillarisetty, V.G. Role of immune cells in pancreatic cancer from bench to clinical application: An updated review. Medicine 2016, 95, e5541.

11. He, M.; Henderson, M.; Muth, S.; Murphy, A.; Zheng, L. Preclinical mouse models for immunotherapeutic and non-immunotherapeutic drug development for pancreatic ductal adenocarcinoma. Annals of Pancreatic Cancer 2020, 3.

12. Upadhrasta, S.; Zheng, L. Strategies in developing immunotherapy for pancreatic cancer: Recognizing and correcting multiple immune "defects" in the tumor microenvironment. Journal of Clinical Medicine 2019, 8.

13. Bazzichetto, C.; Conciatori, F.; Luchini, C.; Simionato, F.; Santoro, R.; Vaccaro, V.; Corbo, V.; Falcone, I.; Ferretti, G.; Cognetti, F., et al. From genetic alterations to tumor microenvironment: The Ariadne's String in pancreatic cancer. Cells 2020, 9.

14. Liu, W.; Kim, G.B.; Krump, N.A.; Zhou, Y.; Riley, J.L.; You, J. Selective reactivation of STING signaling to target Merkel cell carcinoma. Proc Natl Acad Sci U S A 2020, 117, 13730-13739.

15. Harms, P.W.; Harms, K.L.; Moore, P.S.; DeCaprio, J.A.; Nghiem, P.; Wong, M.K.K.; Brownell, I.; International Workshop on Merkel Cell Carcinoma Research Working, G. The biology and treatment of Merkel cell carcinoma: Current understanding and research priorities. Nat Rev Clin Oncol 2018, 15, 763-776.

16. Becker, J.C.; Stang, A.; DeCaprio, J.A.; Cerroni, L.; Lebbe, C.; Veness, M.; Nghiem, P. Merkel cell carcinoma. Nat Rev Dis Primers 2017, 3, 17077.

17. Barber, G.N. Sting: Infection, inflammation and cancer. Nature Reviews Immunology 2015, 15, 760-770.

18. Fu, J.; Kanne, D.B.; Leong, M.; Glickman, L.H.; McWhirter, S.M.; Lemmens, E.; Mechette, K.; Leong, J.J.; Lauer, P.; Liu, W., et al. Sting agonist formulated cancer vaccines can cure established tumors resistant to PD-1 blockade. Science Translational Medicine 2015, 7, 283 ra252.

19. Foote, J.B.; Kok, M.; Leatherman, J.M.; Armstrong, T.D.; Marcinkowski, B.C.; Ojalvo, L.S.; Kanne, D.B.; Jaffee, E.M.; Dubensky, T.W., Jr.; Emens, L.A. A STING agonist given with OX40 receptor and PD-L1 modulators primes immunity and reduces tumor growth in tolerized mice. Cancer Immunology Research 2017, 5, 468-479.

20. Xia, T.; Konno, H.; Ahn, J.; Barber, G.N. Deregulation of sting signaling in colorectal carcinoma constrains DNA damage responses and correlates with tumorigenesis. Cell Rep 2016, 14, 282-297. 
21. Ni, G.; Ma, Z.; Damania, B. Cgas and sting: At the intersection of DNA and RNA virus-sensing networks. PLoS Pathogens 2018, 14, e1007148.

22. Sun, L.; Wu, J.; Du, F.; Chen, X.; Chen, Z.J. Cyclic GMP-AMP synthase is a cytosolic DNA sensor that activates the type I interferon pathway. Science 2013, 339, 786-791.

23. Chen, Q.; Sun, L.; Chen, Z.J. Regulation and function of the cGAS-STING pathway of cytosolic DNA sensing. Nature Immunology 2016, 17, 1142-1149.

24. Cai, X.; Chiu, Y.H.; Chen, Z.J. The cGAS-cGAMP-STING pathway of cytosolic DNA sensing and signaling. Molecular Cell 2014, 54, 289-296.

25. Hubert, M.; Gobbini, E.; Couillault, C.; Manh, T.V.; Doffin, A.C.; Berthet, J.; Rodriguez, C.; Ollion, V.; Kielbassa, J.; Sajous, C., et al. IFN-III is selectively produced by $\mathrm{cDC} 1$ and predicts good clinical outcome in breast cancer. Sci Immunol 2020, 5.

26. Diamond, M.S.; Kinder, M.; Matsushita, H.; Mashayekhi, M.; Dunn, G.P.; Archambault, J.M.; Lee, H.; Arthur, C.D.; White, J.M.; Kalinke, U., et al. Type I interferon is selectively required by dendritic cells for immune rejection of tumors. J Exp Med 2011, 208, 1989-2003.

27. Fuertes, M.B.; Kacha, A.K.; Kline, J.; Woo, S.R.; Kranz, D.M.; Murphy, K.M.; Gajewski, T.F. Host type I IFN signals are required for antitumor CD8+ T cell responses through CD8 $\alpha+$ dendritic cells. J Exp Med 2011, 208, 2005-2016.

28. Zumwalt, T.J.; Arnold, M.; Goel, A.; Boland, C.R. Active secretion of CXCL10 and CCL5 from colorectal cancer microenvironments associates with GranzymeB+ CD8+ T-cell infiltration. Oncotarget 2015, 6, 2981-2991.

29. Mowat, C.; Mosley, S.R.; Namdar, A.; Schiller, D.; Baker, K. Anti-tumor immunity in mismatch repair-deficient colorectal cancers requires type I IFN-driven CCL5 and CXCL10. J Exp Med 2021, 218.

30. Woo, S.R.; Fuertes, M.B.; Corrales, L.; Spranger, S.; Furdyna, M.J.; Leung, M.Y.; Duggan, R.; Wang, Y.; Barber, G.N.; Fitzgerald, K.A., et al. STING-dependent cytosolic DNA sensing mediates innate immune recognition of immunogenic tumors. Immunity 2014, 41, 830-842.

31. Corrales, L.; Glickman, L.H.; McWhirter, S.M.; Kanne, D.B.; Sivick, K.E.; Katibah, G.E.; Woo, S.R.; Lemmens, E.; Banda, T.; Leong, J.J., et al. Direct activation of STING in the tumor microenvironment leads to potent and systemic tumor regression and immunity. Cell Rep 2015, 11, 1018-1030.

32. Lu, X.; Miao, L.; Gao, W.; Chen, Z.; McHugh, K.J.; Sun, Y.; Tochka, Z.; Tomasic, S.; Sadtler, K.; Hyacinthe, A., et al. Engineered PLGA microparticles for longterm, pulsatile release of STING agonist for cancer immunotherapy. Science Translational Medicine 2020, 12.

33. Demaria, O.; De Gassart, A.; Coso, S.; Gestermann, N.; Di Domizio, J.; Flatz, L.; Gaide, O.; Michielin, O.; Hwu, P.; Petrova, T.V., et al. STING activation of tumor endothelial cells initiates spontaneous and therapeutic antitumor immunity. Proc Natl Acad Sci U S A 2015, 112, 15408-15413.

34. Jing, W.; McAllister, D.; Vonderhaar, E.P.; Palen, K.; Riese, M.J.; Gershan, J.; Johnson, B.D.; Dwinell, M.B. STING agonist inflames the pancreatic cancer immune microenvironment and reduces tumor burden in mouse models. $J$ Immunother Cancer 2019, 7, 115. 
35. Wang-Bishop, L.; Wehbe, M.; Shae, D.; James, J.; Hacker, B.C.; Garland, K.; Chistov, P.P.; Rafat, M.; Balko, J.M.; Wilson, J.T. Potent STING activation stimulates immunogenic cell death to enhance antitumor immunity in neuroblastoma. J Immunother Cancer 2020, 8.

36. Pan, B.S.; Perera, S.A.; Piesvaux, J.A.; Presland, J.P.; Schroeder, G.K.; Cumming, J.N.; Trotter, B.W.; Altman, M.D.; Buevich, A.V.; Cash, B., et al. An orally available non-nucleotide STING agonist with antitumor activity. Science 2020, 369.

37. Ramanjulu, J.M.; Pesiridis, G.S.; Yang, J.; Concha, N.; Singhaus, R.; Zhang, S.Y.; Tran, J.L.; Moore, P.; Lehmann, S.; Eberl, H.C., et al. Design of amidobenzimidazole STING receptor agonists with systemic activity. Nature 2018, 564, 439-443.

38. Sivick, K.E.; Desbien, A.L.; Glickman, L.H.; Reiner, G.L.; Corrales, L.; Surh, N.H.; Hudson, T.E.; Vu, U.T.; Francica, B.J.; Banda, T., et al. Magnitude of therapeutic STING activation determines CD8(+) T cell-mediated anti-tumor immunity. Cell Rep 2018, 25, 3074-3085 e3075.

39. Harrington, K.J.; Brody, J.; Ingham, M.; Strauss, J.; Cemerski, S.; Wang, M.; Tse, A.; Khilnani, A.; Marabelle, A.; Golan, T. Preliminary results of the first-in-human (FIH) study of MK-1454, an agonist of stimulator of interferon genes (STING), as monotherapy or in combination with pembrolizumab (pembro) in patients with advanced solid tumors or lymphomas. Ann Oncol 2018, 29, 712-712.

40. Meric-Bernstam, F.; Sandhu, S.K.; Hamid, O.; Spreafico, A.; Kasper, S.; Dummer, R.; Shimizu, T.; Steeghs, N.; Lewis, N.; Talluto, C.C., et al. Phase Ib study of MIW815 (ADU-S100) in combination with spartalizumab (PDR001) in patients (pts) with advanced/metastatic solid tumors or lymphomas. $J$ Clin Oncol 2019, 37.

41. Schadt, L.; Sparano, C.; Schweiger, N.A.; Silina, K.; Cecconi, V.; Lucchiari, G.; Yagita, H.; Guggisberg, E.; Saba, S.; Nascakova, Z., et al. Cancer-cell-intrinsic cGAS expression mediates tumor immunogenicity. Cell Rep 2019, 29, 12361248 e1237.

42. Harding, S.M.; Benci, J.L.; Irianto, J.; Discher, D.E.; Minn, A.J.; Greenberg, R.A. Mitotic progression following DNA damage enables pattern recognition within micronuclei. Nature 2017, 548, 466-470.

43. Xia, T.; Konno, H.; Barber, G.N. Recurrent loss of STING signaling in melanoma correlates with susceptibility to viral oncolysis. Cancer Res 2016, 76, 6747-6759.

44. Chin, E.N.; Yu, C.; Vartabedian, V.F.; Jia, Y.; Kumar, M.; Gamo, A.M.; Vernier, W.; Ali, S.H.; Kissai, M.; Lazar, D.C., et al. Antitumor activity of a systemic STING-activating non-nucleotide cGAMP mimetic. Science (New York, N.Y.) 2020, 369, 993-999.

45. Gajewski, T.F.; Higgs, E.F. Immunotherapy with a STING. Science (New York, N.Y.) 2020, 369, 921-922.

46. Luksch, H.; Stinson, W.A.; Platt, D.J.; Qian, W.; Kalugotla, G.; Miner, C.A.; Bennion, B.G.; Gerbaulet, A.; Rösen-Wolff, A.; Miner, J.J. STING-associated lung disease in mice relies on $\mathrm{T}$ cells but not type I interferon. The Journal of Allergy and clinical Immunology 2019, 144, 254-266.e258. 
47. Konno, H.; Chinn, I.K.; Hong, D.; Orange, J.S.; Lupski, J.R.; Mendoza, A.; Pedroza, L.A.; Barber, G.N. Pro-inflammation associated with a gain-of-function mutation (R284S) in the innate immune sensor STING. Cell Rep 2018, 23, 11121123.

48. Jeremiah, N.; Neven, B.; Gentili, M.; Callebaut, I.; Maschalidi, S.; Stolzenberg, M.C.; Goudin, N.; Frémond, M.L.; Nitschke, P.; Molina, T.J., et al. Inherited STING-activating mutation underlies a familial inflammatory syndrome with lupus-like manifestations. The Journal of Clinical Investigation 2014, 124, 55165520.

49. Liu, Y.; Jesus, A.A.; Marrero, B.; Yang, D.; Ramsey, S.E.; Sanchez, G.A.M.; Tenbrock, K.; Wittkowski, H.; Jones, O.Y.; Kuehn, H.S., et al. Activated STING in a vascular and pulmonary syndrome. The New England Journal of Medicine 2014, 371, 507-518.

50. König, N.; Fiehn, C.; Wolf, C.; Schuster, M.; Cura Costa, E.; Tüngler, V.; Alvarez, H.A.; Chara, O.; Engel, K.; Goldbach-Mansky, R., et al. Familial chilblain lupus due to a gain-of-function mutation in STING. Annals of the Rheumatic Diseases 2017, 76, 468-472.

51. Melki, I.; Rose, Y.; Uggenti, C.; Van Eyck, L.; Frémond, M.L.; Kitabayashi, N.; Rice, G.I.; Jenkinson, E.M.; Boulai, A.; Jeremiah, N., et al. Disease-associated mutations identify a novel region in human sting necessary for the control of type I interferon signaling. The Journal of Allergy and Clinical Immunology 2017, 140, 543-552.e545.

52. Bennion, B.G.; Ingle, H.; Ai, T.L.; Miner, C.A.; Platt, D.J.; Smith, A.M.; Baldridge, M.T.; Miner, J.J. A human gain-of-function sting mutation causes immunodeficiency and gammaherpesvirus-induced pulmonary fibrosis in mice. Journal of Virology 2019, 93, e01806-01818.

53. Bouis, D.; Kirstetter, P.; Arbogast, F.; Lamon, D.; Delgado, V.; Jung, S.; Ebel, C.; Jacobs, H.; Knapp, A.M.; Jeremiah, N., et al. Severe combined immunodeficiency in stimulator of interferon genes (STING) V154M/wild-type mice. The Journal of allergy and Clinical Immunology 2019, 143, 712-725.e715.

54. Dobbs, N.; Burnaevskiy, N.; Chen, D.; Gonugunta, V.K.; Alto, N.M.; Yan, N. STING activation by translocation from the ER is associated with infection and autoinflammatory disease. Cell Host \& Microbe 2015, 18, 157-168.

55. Gulen, M.F.; Koch, U.; Haag, S.M.; Schuler, F.; Apetoh, L.; Villunger, A.; Radtke, F.; Ablasser, A. Signalling strength determines proapoptotic functions of STING. Nat Commun 2017, 8, 427.

56. Keskitalo, S.; Haapaniemi, E.; Einarsdottir, E.; Rajamäki, K.; Heikkilä, H.; Ilander, M.; Pöyhönen, M.; Morgunova, E.; Hokynar, K.; Lagström, S., et al. Novel TMEM173 mutation and the role of disease modifying alleles. Frontiers in Immunology 2019, 10, 2770.

57. Li, Y.; Wilson, H.L.; Kiss-Toth, E. Regulating sting in health and disease. Journal of Inflammation 2017, 14, 11.

58. Munoz, J.; Rodière, M.; Jeremiah, N.; Rieux-Laucat, F.; Oojageer, A.; Rice, G.I.; Rozenberg, F.; Crow, Y.J.; Bessis, D. Stimulator of interferon genes-associated vasculopathy with onset in infancy: A mimic of childhood granulomatosis with polyangiitis. JAMA Dermatology 2015, 151, 872-877. 
59. Patel, S.; Jin, L. Tmem173 variants and potential importance to human biology and disease. Genes \& Immunity 2019, 20, 82-89.

60. Tang, E.D.; Wang, C.-Y. Single amino acid change in sting leads to constitutive active signaling. PLOS ONE 2015, 10, e0120090.

61. Warner, J.D.; Irizarry-Caro, R.A.; Bennion, B.G.; Ai, T.L.; Smith, A.M.; Miner, C.A.; Sakai, T.; Gonugunta, V.K.; Wu, J.; Platt, D.J., et al. STING-associated vasculopathy develops independently of IRF3 in mice. J Exp Med 2017, 214, 3279-3292.

62. Zapata, M.; Cohen, C.; Siddiqui, M.T. Immunohistochemical expression of SMAD4, CK19, and CA19-9 in fine needle aspiration samples of pancreatic adenocarcinoma: Utility and potential role. Cytojournal 2007, 4, 13.

63. Gonugunta, V.K.; Sakai, T.; Pokatayev, V.; Yang, K.; Wu, J.; Dobbs, N.; Yan, N. Trafficking-mediated STING degradation requires sorting to acidified endolysosomes and can be targeted to enhance anti-tumor response. Cell Rep 2017, 21, 3234-3242.

64. Liu, W.; Reyes, H.M.; Yang, J.F.; Li, Y.; Stewart, K.M.; Basil, M.C.; Lin, S.M.; Katzen, J.; Morrisey, E.E.; Weiss, S.R., et al. Activation of STING signaling pathway effectively blocks human coronavirus infection. J Virol 2021, 95.

65. Prabakaran, T.; Bodda, C.; Krapp, C.; Zhang, B.C.; Christensen, M.H.; Sun, C.; Reinert, L.; Cai, Y.; Jensen, S.B.; Skouboe, M.K., et al. Attenuation of cGASSTING signaling is mediated by a P62/SQSTM1-dependent autophagy pathway activated by TBK1. EMBO J 2018, 37.

66. Yum, S.; Li, M.; Chen, Z.J. Old dogs, new trick: Classic cancer therapies activate cGAS. Cell Research 2020, 30, 639-648.

67. Yamashiro, L.H.; Wilson, S.C.; Morrison, H.M.; Karalis, V.; Chung, J.J.; Chen, K.J.; Bateup, H.S.; Szpara, M.L.; Lee, A.Y.; Cox, J.S., et al. Interferonindependent STING signaling promotes resistance to HSV-1 in vivo. Nat Commun 2020, 11, 3382.

68. Gao, D.; Wu, J.; Wu, Y.T.; Du, F.; Aroh, C.; Yan, N.; Sun, L.; Chen, Z.J. Cyclic gmp-amp synthase is an innate immune sensor of hiv and other retroviruses. Science 2013, 341, 903-906.

69. Mitchell, M.J.; Billingsley, M.M.; Haley, R.M.; Wechsler, M.E.; Peppas, N.A.; Langer, R. Engineering precision nanoparticles for drug delivery. Nature Reviews Drug Discovery 2021, 20, 101-124.

70. Alameh, M.G.; Tombacz, I.; Bettini, E.; Lederer, K.; Sittplangkoon, C.; Wilmore, J.R.; Gaudette, B.T.; Soliman, O.Y.; Pine, M.; Hicks, P., et al. Lipid nanoparticles enhance the efficacy of mRNA and protein subunit vaccines by inducing robust $T$ follicular helper cell and humoral responses. Immunity 2021.

71. Pardi, N.; Hogan, M.J.; Pelc, R.S.; Muramatsu, H.; Andersen, H.; DeMaso, C.R.; Dowd, K.A.; Sutherland, L.L.; Scearce, R.M.; Parks, R., et al. Zika virus protection by a single low-dose nucleoside-modified mRNA vaccination. Nature 2017, 543, 248-251.

72. Kariko, K.; Buckstein, M.; Ni, H.; Weissman, D. Suppression of rna recognition by toll-like receptors: The impact of nucleoside modification and the evolutionary origin of RNA. Immunity 2005, 23, 165-175. 
73. Kariko, K.; Weissman, D. Naturally occurring nucleoside modifications suppress the immunostimulatory activity of RNA: Implication for therapeutic RNA development. Curr Opin Drug Discov Devel 2007, 10, 523-532.

74. Anderson, B.R.; Muramatsu, H.; Jha, B.K.; Silverman, R.H.; Weissman, D.; Kariko, K. Nucleoside modifications in RNA limit activation of 2'-5'-oligoadenylate synthetase and increase resistance to cleavage by RNase I. Nucleic Acids Res 2011, 39, 9329-9338.

75. Kariko, K.; Muramatsu, H.; Welsh, F.A.; Ludwig, J.; Kato, H.; Akira, S.; Weissman, D. Incorporation of pseudouridine into mRNA yields superior nonimmunogenic vector with increased translational capacity and biological stability. Mol Ther 2008, 16, 1833-1840.

76. Anderson, B.R.; Muramatsu, H.; Nallagatla, S.R.; Bevilacqua, P.C.; Sansing, L.H.; Weissman, D.; Kariko, K. Incorporation of pseudouridine into mRNA enhances translation by diminishing PKR activation. Nucleic Acids Res 2010, 38, 5884-5892.

77. Kariko, K.; Muramatsu, H.; Ludwig, J.; Weissman, D. Generating the optimal mRNA for therapy: HPLC purification eliminates immune activation and improves translation of nucleoside-modified, protein-encoding mRNA. Nucleic Acids Res 2011, 39, e142.

78. Sahin, U.; Oehm, P.; Derhovanessian, E.; Jabulowsky, R.A.; Vormehr, M.; Gold, M.; Maurus, D.; Schwarck-Kokarakis, D.; Kuhn, A.N.; Omokoko, T., et al. An RNA vaccine drives immunity in checkpoint-inhibitor-treated melanoma. Nature 2020, 585, 107-112.

79. Awasthi, S.; Hook, L.M.; Pardi, N.; Wang, F.; Myles, A.; Cancro, M.P.; Cohen, G.H.; Weissman, D.; Friedman, H.M. Nucleoside-modified mrna encoding HSV-2 glycoproteins $\mathrm{c}, \mathrm{d}$, and e prevents clinical and subclinical genital herpes. Sci Immunol 2019, 4.

80. LaTourette, P.C., 2nd; Awasthi, S.; Desmond, A.; Pardi, N.; Cohen, G.H.; Weissman, D.; Friedman, H.M. Protection against herpes simplex virus type 2 infection in a neonatal murine model using a trivalent nucleoside-modified mrna in lipid nanoparticle vaccine. Vaccine 2020, 38, 7409-7413.

81. Awasthi, S.; Knox, J.J.; Desmond, A.; Alameh, M.G.; Gaudette, B.T.; Lubinski, J.M.; Naughton, A.; Hook, L.M.; Egan, K.P.; Tam, Y.K., et al. Trivalent nucleoside-modified mRNA vaccine yields durable memory B cell protection against genital herpes in preclinical models. The Journal of Clinical Investigation 2021, 131.

82. Pardi, N.; Tuyishime, S.; Muramatsu, H.; Kariko, K.; Mui, B.L.; Tam, Y.K.; Madden, T.D.; Hope, M.J.; Weissman, D. Expression kinetics of nucleosidemodified mRNA delivered in lipid nanoparticles to mice by various routes. $J$ Control Release 2015, 217, 345-351.

83. Chaudhary, N.; Weissman, D.; Whitehead, K.A. MRNA vaccines for infectious diseases: Principles, delivery and clinical translation. Nat Rev Drug Discov 2021.

84. Akinc, A.; Querbes, W.; De, S.; Qin, J.; Frank-Kamenetsky, M.; Jayaprakash, K.N.; Jayaraman, M.; Rajeev, K.G.; Cantley, W.L.; Dorkin, J.R., et al. Targeted delivery of RNAi therapeutics with endogenous and exogenous ligand-based mechanisms. Mol Ther 2010, 18, 1357-1364. 
85. Sebastiani, F.; Yanez Arteta, M.; Lerche, M.; Porcar, L.; Lang, C.; Bragg, R.A.; Elmore, C.S.; Krishnamurthy, V.R.; Russell, R.A.; Darwish, T., et al. Apolipoprotein $\mathrm{E}$ binding drives structural and compositional rearrangement of mRNA-containing lipid nanoparticles. ACS Nano 2021, 15, 6709-6722.

86. Feng, H.; Shuda, M.; Chang, Y.; Moore, P.S. Clonal integration of a polyomavirus in human Merkel cell carcinoma. Science 2008, 319, 1096-1100.

87. Park, D.E.; Cheng, J.; McGrath, J.P.; Lim, M.Y.; Cushman, C.; Swanson, S.K.; Tillgren, M.L.; Paulo, J.A.; Gokhale, P.C.; Florens, L., et al. Merkel cell polyomavirus activates LSD1-mediated blockade of non-canonical BAF to regulate transformation and tumorigenesis. Nat Cell Biol 2020, 22, 603-615.

88. O'Reilly, E.M.; Oh, D.Y.; Dhani, N.; Renouf, D.J.; Lee, M.A.; Sun, W.; Fisher, G.; Hezel, A.; Chang, S.C.; Vlahovic, G., et al. Durvalumab with or without tremelimumab for patients with metastatic pancreatic ductal adenocarcinoma: A Phase 2 randomized clinical trial. JAMA Oncol 2019, 5, 1431-1438.

89. Nghiem, P.; Bhatia, S.; Lipson, E.J.; Sharfman, W.H.; Kudchadkar, R.R.; Brohl, A.S.; Friedlander, P.A.; Daud, A.; Kluger, H.M.; Reddy, S.A., et al. Three-year survival, correlates and salvage therapies in patients receiving first-line pembrolizumab for advanced Merkel cell carcinoma. J Immunother Cancer 2021, 9.

90. Carstens, J.L.; Correa de Sampaio, P.; Yang, D.; Barua, S.; Wang, H.; Rao, A.; Allison, J.P.; LeBleu, V.S.; Kalluri, R. Spatial computation of intratumoral T cells correlates with survival of patients with pancreatic cancer. Nat Commun 2017, 8, 15095.

91. Clark, C.E.; Hingorani, S.R.; Mick, R.; Combs, C.; Tuveson, D.A.; Vonderheide, R.H. Dynamics of the immune reaction to pancreatic cancer from inception to invasion. Cancer Res 2007, 67, 9518-9527.

92. Karamitopoulou, E. The tumor microenvironment of pancreatic cancer. Cancers (Basel) 2020, 12.

93. Dall'Olio, F.G.; Marabelle, A.; Caramella, C.; Garcia, C.; Aldea, M.; Chaput, N.; Robert, C.; Besse, B. Tumour burden and efficacy of immune-checkpoint inhibitors. Nat Rev Clin Oncol 2021.

94. Huang, A.C.; Postow, M.A.; Orlowski, R.J.; Mick, R.; Bengsch, B.; Manne, S.; Xu, W.; Harmon, S.; Giles, J.R.; Wenz, B., et al. T-cell invigoration to tumour burden ratio associated with anti-PD-1 response. Nature 2017, 545, 60-65.

95. Knudson, C.J.; Alves-Peixoto, P.; Muramatsu, H.; Stotesbury, C.; Tang, L.; Lin, P.J.C.; Tam, Y.K.; Weissman, D.; Pardi, N.; Sigal, L.J. Lipid-nanoparticleencapsulated mRNA vaccines induce protective memory CD8 T cells against a lethal viral infection. Mol Ther 2021, 29, 2769-2781.

96. Munakata, L.; Tanimoto, Y.; Osa, A.; Meng, J.; Haseda, Y.; Naito, Y.; Machiyama, H.; Kumanogoh, A.; Omata, D.; Maruyama, K., et al. Lipid nanoparticles of Type-A CpG D35 suppress tumor growth by changing tumor immune-microenvironment and activate CD8 $\mathrm{T}$ cells in mice. Journal of Controlled Release 2019, 313, 106-119.

97. Yanagi, T.; Tachikawa, K.; Wilkie-Grantham, R.; Hishiki, A.; Nagai, K.; Toyonaga, E.; Chivukula, P.; Matsuzawa, S. Lipid nanoparticle-mediated sirna transfer 
against PCTAIRE1/PCTK1/Cdk16 inhibits in vivo cancer growth. Molecular Therapy Nucleic Acids 2016, 5, e327.

98. Hewitt, S.L.; Bai, A.; Bailey, D.; Ichikawa, K.; Zielinski, J.; Karp, R.; Apte, A.; Arnold, K.; Zacharek, S.J.; Iliou, M.S., et al. Durable anticancer immunity from intratumoral administration of IL-23, IL-36y, and OX40I mrnas. Science Translational Medicine 2019, 11.

99. Hewitt, S.L.; Bailey, D.; Zielinski, J.; Apte, A.; Musenge, F.; Karp, R.; Burke, S.; Garcon, F.; Mishra, A.; Gurumurthy, S., et al. Intratumoral IL12 mrna therapy promotes $\mathrm{TH} 1$ transformation of the tumor microenvironment. Clin Cancer Res 2020, 26, 6284-6298.

100. Larkin, B.; Ilyukha, V.; Sorokin, M.; Buzdin, A.; Vannier, E.; Poltorak, A. Cutting edge: Activation of STING in T cells induces type I IFN responses and cell death. $\mathrm{J}$ Immunol 2017, 199, 397-402.

101. Cerboni, S.; Jeremiah, N.; Gentili, M.; Gehrmann, U.; Conrad, C.; Stolzenberg, M.C.; Picard, C.; Neven, B.; Fischer, A.; Amigorena, S., et al. Intrinsic antiproliferative activity of the innate sensor sting in $\mathrm{T}$ lymphocytes. The Journal of Experimental Medicine 2017, 214, 1769-1785.

102. Gaidt, M.M.; Ebert, T.S.; Chauhan, D.; Ramshorn, K.; Pinci, F.; Zuber, S.; O'Duill, F.; Schmid-Burgk, J.L.; Hoss, F.; Buhmann, R., et al. The DNA inflammasome in human myeloid cells is initiated by a STING-cell death program upstream of NLRP3. Cell 2017, 171, 1110-1124.e1118.

103. Ahn, J.; Xia, T.; Konno, H.; Konno, K.; Ruiz, P.; Barber, G.N. Inflammation-driven carcinogenesis is mediated through STING. Nat Commun 2014, 5, 5166.

104. Tombacz, I.; Laczko, D.; Shahnawaz, H.; Muramatsu, H.; Natesan, A.; Yadegari, A.; Papp, T.E.; Alameh, M.G.; Shuvaev, V.; Mui, B.L., et al. Highly efficient CD4+ $T$ cell targeting and genetic recombination using engineered CD4+ cell-homing mRNA-LNP. Mol Ther 2021.

105. Corrales, L.; Gajewski, T.F. Molecular pathways: Targeting the stimulator of interferon genes (STING) in the immunotherapy of cancer. Clinical Cancer Research : an official journal of the American Association for Cancer Research 2015, 21, 4774-4779.

106. Liu, W.; Yang, R.; Payne, A.S.; Schowalter, R.M.; Spurgeon, M.E.; Lambert, P.F.; $\mathrm{Xu}, \mathrm{X}$.; Buck, C.B.; You, J. Identifying the target cells and mechanisms of Merkel cell polyomavirus infection. Cell Host \& Microbe 2016, 19, 775-787.

107. Liu, W.; Krump, N.A.; Herlyn, M.; You, J. Combining DNA damage induction with BCL-2 inhibition to enhance merkel cell carcinoma cytotoxicity. Biology (Basel) 2020, 9.

108. Liu, W.; Stein, P.; Cheng, X.; Yang, W.; Shao, N.Y.; Morrisey, E.E.; Schultz, R.M.; You, J. BRD4 regulates nanog expression in mouse embryonic stem cells and preimplantation embryos. Cell Death Differ 2014, 21, 1950-1960. 


\section{Figure legends}

Figure 1. STING is downregulated in PDAC. (A) Whole-cell lysates of PDAC cells and primary HDF cells were immunoblotted using the indicated antibodies. GAPDH was used as a loading control. (B) PDAC lesions were stained for STING (Green) and CK19 (Red), and counterstained with DAPI. Shown are the staining results of pancreatic lesions derived from 7 different patients.

Figure 2. Identification of highly effective STING gain-of-function mutants. (A) MIA PaCa-2 cells stably expressing STING ${ }^{\mathrm{WT}}$, STING ${ }^{\mathrm{V} 147 \mathrm{~L}}$, STING ${ }^{\mathrm{N} 154 \mathrm{~S}}$, STING ${ }^{\mathrm{V} 155 \mathrm{M}}$ or STING ${ }^{\text {R284S }}$ were treated with or without $5 \mu \mathrm{g} / \mathrm{mL}$ dox for $48 \mathrm{~h}$. The cells were stained for STING (Red) and Cleaved Caspase-3 (Green). (B) MIA PaCa-2 cells stably expressing STING ${ }^{\mathrm{WT}}$, STING ${ }^{\mathrm{V} 147 \mathrm{~L}}$, STING ${ }^{\mathrm{N} 154 \mathrm{~S}}$, STING $^{\mathrm{V} 155 \mathrm{M}}$, or STING ${ }^{\mathrm{R} 284 \mathrm{~S}}$ were treated with or without $5 \mu \mathrm{g} / \mathrm{mL}$ dox. At $96 \mathrm{~h}$ post-treatment, cell viability was measured by the Titer-GLO 3D cell viability assay (ns: not significant, ${ }^{*} P<0.05,{ }^{* *} P<0.01$, ${ }^{* * *} P<$ $0.001)$.

Figure 3. Ectopic expression of dox-inducible STING ${ }^{\text {R284S }}$ induces key anti-tumor cytokine production and cell death in PDAC cells. (A-C) MIA PaCa-2 cells stably expressing STING ${ }^{W T}$ or STING ${ }^{R 284}$ were treated with or without $5 \mu \mathrm{g} / \mathrm{mL}$ dox for $48 \mathrm{~h}$. (A) The cells were stained for STING (Red) and Cleaved Caspase-3 (Green). (B) STING ${ }^{\text {WT }}$ and STING ${ }^{\text {R284S }}$ expression was confirmed by RT-qPCR. (C) The mRNA levels of the indicated genes were measured by RT-qPCR and normalized to GAPDH mRNA levels. The values for untreated STING ${ }^{W T}$ cells were set to 1. (D) MIA PaCa-2 cells stably expressing STING ${ }^{W T}$ or STING ${ }^{R 284 S}$ were treated with or without $5 \mu \mathrm{g} / \mathrm{mL}$ dox. At $96 \mathrm{~h}$ post-treatment, cell viability was measured by the Titer-GLO 3D cell viability assay. Error bars represent SEM of three independent experiments. (ns: not significant, $\left.{ }^{*} \mathrm{P}<0.05,{ }^{* *} \mathrm{P}<0.01,{ }^{* * *} \mathrm{P}<0.001\right)$.

Figure 4. Transfection of STING ${ }^{\text {2284S }}$ mRNA activates vital anti-tumor cytokine production and triggers PDAC cell death. (A-C) $10 e^{4} \mathrm{MIA} \mathrm{PaCa}-2$ cells were transfected with $0.5 \mu \mathrm{g}$ STING ${ }^{\mathrm{WT}}$ or STING ${ }^{\mathrm{R} 284 \mathrm{~S}}$ mRNA. At $15 \mathrm{~h}$ post-transfection, cells were stained for STING (Red) and Cleaved Caspase-3 (Green) (A), STING ${ }^{\text {WT }}$ and STING ${ }^{R 24 S}$ expression was confirmed by RT-qPCR (B), and the mRNA levels of the indicated genes were measured by RT-qPCR and normalized to the GAPDH mRNA level (C). The values for untreated cells (Mock) were set to 1. (D) $0.5 \times 10 e^{4}$ MIA PaCa-2 cells were transfected with $1 \mu \mathrm{g}$ STING ${ }^{W T}$ or STING ${ }^{\text {R284S }}$ mRNA. At $15 \mathrm{~h}$ posttransfection, cell viability was measured by the Titer-GLO 3D cell viability assay. Error bars represent SEM of three independent experiments. (ns: not significant, ${ }^{*} \mathrm{P}<0.05$, $\left.{ }^{* *} \mathrm{P}<0.01,{ }^{* * *} \mathrm{P}<0.001\right)$.

Figure 5. STING ${ }^{R 284 S}$ delivered by mRNA-LNP activates essential anti-tumor cytokine production and kills PDAC cells. (A) $2 \times 10 e^{4} \mathrm{MIA} \mathrm{PaCa-2}$ cells were treated with $1 \mu \mathrm{g}$ STING ${ }^{W T}$ or STING ${ }^{R 284}$ mRNA-LNP, which were pre-mixed with the indicated concentration of the recombinant human APOE4 protein. At $16 \mathrm{~h}$ post-transfection, cells were stained for STING (Red) and Cleaved Caspase-3 (Green). (B-C) 10e ${ }^{4}$ MIA PaCa-2 
cells were treated as in (A) using $10 \mu \mathrm{g} / \mathrm{ml}$ human APOE4 protein. At $16 \mathrm{~h}$ posttransfection, STING ${ }^{W T}$ and STING ${ }^{\text {R284S }}$ expression was confirmed by RT-qPCR (B), and the mRNA levels of the indicated genes were measured by RT-qPCR and normalized to the GAPDH mRNA level (C). The values for untreated cells (Mock) were set to 1. (D) $0.5 \times 10 e^{4}$ MIA PaCa-2 cells were treated as in (B). At 16 h post-transfection, cell viability was measured by the Titer-GLO 3D cell viability assay. Error bars represent SEM of three independent experiments. (ns: not significant, ${ }^{*} \mathrm{P}<0.05,{ }^{* *} \mathrm{P}<0.01,{ }^{* * *} \mathrm{P}<$ 0.001).

Figure 6. STING ${ }^{R 284 S}$ mRNA-LNP can trigger vital anti-tumor cytokine production and cell death in MCC cells. (A) $10 e^{4}$ MKL-1 cells were treated with $1 \mu \mathrm{g}$ STING ${ }^{\mathrm{WT}}$ or STING ${ }^{R 284}$ mRNA-LNP, which were pre-mixed with the indicated concentration of the recombinant human APOE4 protein. At 16h post-transfection, cells were stained for STING (Red) and Cleaved Caspase-3 (Green). (B-C) 10e $\mathrm{e}^{4} \mathrm{MKL}-1$ cells were treated as in $(A)$ using $10 \mu \mathrm{g} / \mathrm{ml}$ human APOE4 protein. At $16 \mathrm{~h}$ post-transfection, STING ${ }^{W T}$ and STING ${ }^{R 24 S}$ expression was confirmed by RT-qPCR (B), and the mRNA levels of the indicated genes were measured by RT-qPCR and normalized to the GAPDH mRNA level (C). The values for untreated cells (Mock) were set to 1. (D) $0.5 \times 10 e^{4} \mathrm{MKL}-1$ cells were treated as in $(B)$ at 0 and $24 \mathrm{~h}$. At $40 \mathrm{~h}$ post-transfection, cell viability was measured by the Titer-GLO 3D cell viability assay. Error bars represent SEM of three independent experiments. (ns: not significant, ${ }^{*} \mathrm{P}<0.05,{ }^{* *} \mathrm{P}<0.01,{ }^{* * *} \mathrm{P}<0.001$ ).

Figure S1. Ectopic expression of dox-inducible STING ${ }^{\text {R284 }}$ stimulates key antitumor cytokine production and cancer cell death in PDAC cells. (A-C) BxPC-3 cells stably expressing STING ${ }^{W T}$ or STING ${ }^{R 284 S}$ were treated with or without $5 \mu \mathrm{g} / \mathrm{mL}$ dox for $24 \mathrm{~h}$. (A) The cells were stained for STING (Red) and Cleaved Caspase-3 (Green). (B) STING ${ }^{W T}$ and STING ${ }^{\text {R284S }}$ expression was confirmed by RT-qPCR. (C) The mRNA levels of the indicated genes were measured by RT-qPCR and normalized to the GAPDH mRNA level. The values for untreated STING ${ }^{W T}$ cells were set to 1. (D) BxPC-3 cells stably expressing STING ${ }^{W T}$ or STING ${ }^{\text {2284S }}$ were treated with or without $5 \mu \mathrm{g} / \mathrm{mL}$ Dox. At $72 \mathrm{~h}$ post-treatment, cell viability was measured by the Titer-GLO 3D cell viability assay. Error bars represent SEM of three independent experiments. (ns: not significant, $\left.{ }^{*} \mathrm{P}<0.05,{ }^{* *} \mathrm{P}<0.01,{ }^{* * *} \mathrm{P}<0.001\right)$.

Figure S2. Transfection of STING ${ }^{\text {R284S }}$ mRNA activates vital anti-tumor cytokine production and triggers PDAC cell death. (A-C) BXPC-3 cells were transfected with $0.5 \mu \mathrm{g}$ STING ${ }^{\mathrm{WT}}$ or STING ${ }^{\mathrm{R} 284 \mathrm{~S}}$ mRNA. At $15 \mathrm{~h}$ post-transfection, cells were stained for STING (Red) and Cleaved Caspase-3 (Green) (A), STINGWT and STING ${ }^{\text {R284S }}$ expression was confirmed by RT-qPCR (B), and the mRNA levels of the indicated genes were measured by RT-qPCR and normalized to the GAPDH mRNA level (C). The values for untreated cells (Mock) were set to 1. (D) BxPC-3 cells were transfected with $1 \mu \mathrm{g}$ STING ${ }^{W T}$ or STING ${ }^{\mathrm{R} 284 \mathrm{~S}}$ mRNA. At $15 \mathrm{~h}$ post-transfection, cell viability was measured by the Titer-GLO 3D cell viability assay. Error bars represent SEM of three independent experiments. (ns: not significant, ${ }^{*} P<0.05,{ }^{* *} P<0.01,{ }^{* * *} P<0.001$ ). 
Figure S3. STING ${ }^{\text {R284S }}$ delivered by mRNA-LNP activates essential anti-tumor cytokine production and kills PDAC cells. (A) $10 \mathrm{e}^{4} \mathrm{BxPC}-3$ cells were treated with 1 $\mu \mathrm{g}$ STING ${ }^{W T}$ or STING ${ }^{R 285}$ mRNA-LNP, which were pre-mixed with the indicated concentration of the recombinant human APOE4 protein. At 16h post-transfection, cells were stained for STING (Red) and Cleaved Caspase-3 (Green). (B-C) $10 e^{4}$ BxPC-3 cells were treated with $1 \mu \mathrm{g}$ STING ${ }^{\mathrm{WT}}$ or STING ${ }^{\mathrm{R} 284 \mathrm{~S}}$ mRNA-LNP, which were pre-mixed with $10 \mu \mathrm{g} / \mathrm{ml}$ human APOE4 protein. At 16h post-transfection, STING ${ }^{\mathrm{WT}}$ and STING ${ }^{\text {R284 }}$ expression was confirmed by RT-qPCR (B), and the mRNA levels of the indicated genes were measured by RT-qPCR and normalized to GAPDH mRNA levels (C). The values for untreated cells (Mock) were set to 1. (D) $0.5 \times 10 e^{4}$ BxPC-3 cells were treated with $1 \mu \mathrm{g}$ STING ${ }^{\mathrm{WT}}$ or STING ${ }^{\mathrm{R} 284 \mathrm{~S}}$ mRNA-LNP, which were pre-mixed with 10 $\mu \mathrm{g} / \mathrm{ml}$ APOE4 protein. At 16h post-transfection, cell viability was measured by Titer-GLO 3D cell viability assay. (E) $10 \mathrm{e}^{4} \mathrm{CD}^{+} \mathrm{T}$ cells were treated with $1 \mu \mathrm{g}$ STING ${ }^{\mathrm{WT}}$ or STING ${ }^{R 284}$ mRNA-LNP, which were pre-mixed with $10 \mu \mathrm{g} / \mathrm{ml}$ APOE4 protein. At $16 \mathrm{~h}$ post-transfection, cell viability was measured by the Titer-GLO 3D cell viability assay. Error bars represent SEM of three independent experiments. (ns: not significant, ${ }^{*} \mathrm{P}<$ $\left.0.05,{ }^{* *} \mathrm{P}<0.01,{ }^{* * *} \mathrm{P}<0.001\right)$.

Figure S4. STING is silenced in classic MCPyV ${ }^{+}$MCC cell lines. (A) The mRNA level (HTseq count) of STING in MKL-1 MKL-2, MS-1, WaGa, PeTa, BroLi, and UISO cells was calculated based on published RNA-seq data [87]. Error bars represent SEM of three independent experiments. (ns: not significant, ${ }^{*} P<0.05$, ${ }^{* *} P<0.01,{ }^{* * *} P<$ 0.001). (B) Whole-cell lysates of PeTa, MS-1, UISO, MCC13 and primary HDF cells were immunoblotted using the indicated antibodies. GAPDH was used as a loading control.

Figure S5. Optimizing the conditions for mRNA-LNP delivery in MCC cells. $10 e^{4}$ MKL-1 and MS-1 cells were treated with $1 \mu \mathrm{g}$ firefly luciferase mRNA-LNP, which were pre-mixed with the indicated concentration of the recombinant human APOE4 protein. At $16 \mathrm{~h}$ post-transfection, firefly luciferase activity was measured using a luciferase reporter assay system kit (Promega). (ns: not significant, ${ }^{*} P<0.05,{ }^{* *} P<0.01,{ }^{* * *} P<$ 0.001).

Figure S6. STING ${ }^{\text {R284S }}$ mRNA-LNP can trigger vital anti-tumor cytokine production and cell death in MCC cells. (A) $10 \mathrm{e}^{4} \mathrm{MS}-1$ cells were treated with $1 \mu \mathrm{gg}$ STING ${ }^{\mathrm{WT}}$ or STING ${ }^{\text {R284S }}$ mRNA-LNP, which were pre-mixed with the indicated concentration of the recombinant human APOE4 protein. At 16h post-transfection, cells were stained for STING (Red) and Cleaved Caspase-3 (Green). (B-C) $10 \mathrm{e}^{4} \mathrm{MS}-1$ cells were treated with $1 \mu \mathrm{g}$ STING ${ }^{W T}$ or STING ${ }^{\text {R284S }}$ mRNA-LNP, which were pre-mixed with $10 \mu \mathrm{g} / \mathrm{ml}$ human APOE4 protein. At 16h post-transfection, STING ${ }^{W T}$ and STING ${ }^{\text {R284S }}$ expression was confirmed by RT-qPCR (B), and the mRNA levels of the indicated genes were measured by RT-qPCR and normalized to GAPDH mRNA levels (C). The values for untreated cells (Mock) were set to 1 . (D) $0.5 \times 10 e^{4} \mathrm{MS}-1$ cells were treated with $1 \mu \mathrm{g}$ STING ${ }^{W T}$ or STING ${ }^{\text {R284S }}$ mRNA-LNP, which were pre-mixed with $10 \mu \mathrm{g} / \mathrm{ml}$ APOE4 protein at $0 \mathrm{~h}$ and $24 \mathrm{~h}$. At $40 \mathrm{~h}$ post-transfection, cell viability was measured by the Titer- 
bioRxiv preprint doi: https://doi.org/10.1101/2022.01.08.475499; this version posted January 12, 2022. The copyright holder for this preprint (which was not certified by peer review) is the author/funder. All rights reserved. No reuse allowed without permission.

GLO 3D cell viability assay. Error bars represent SEM of three independent experiments. (ns: not significant, ${ }^{*} \mathrm{P}<0.05,{ }^{* *} \mathrm{P}<0.01,{ }^{* * *} \mathrm{P}<0.001$ ). 
Figure 1
$\mathrm{~A}$

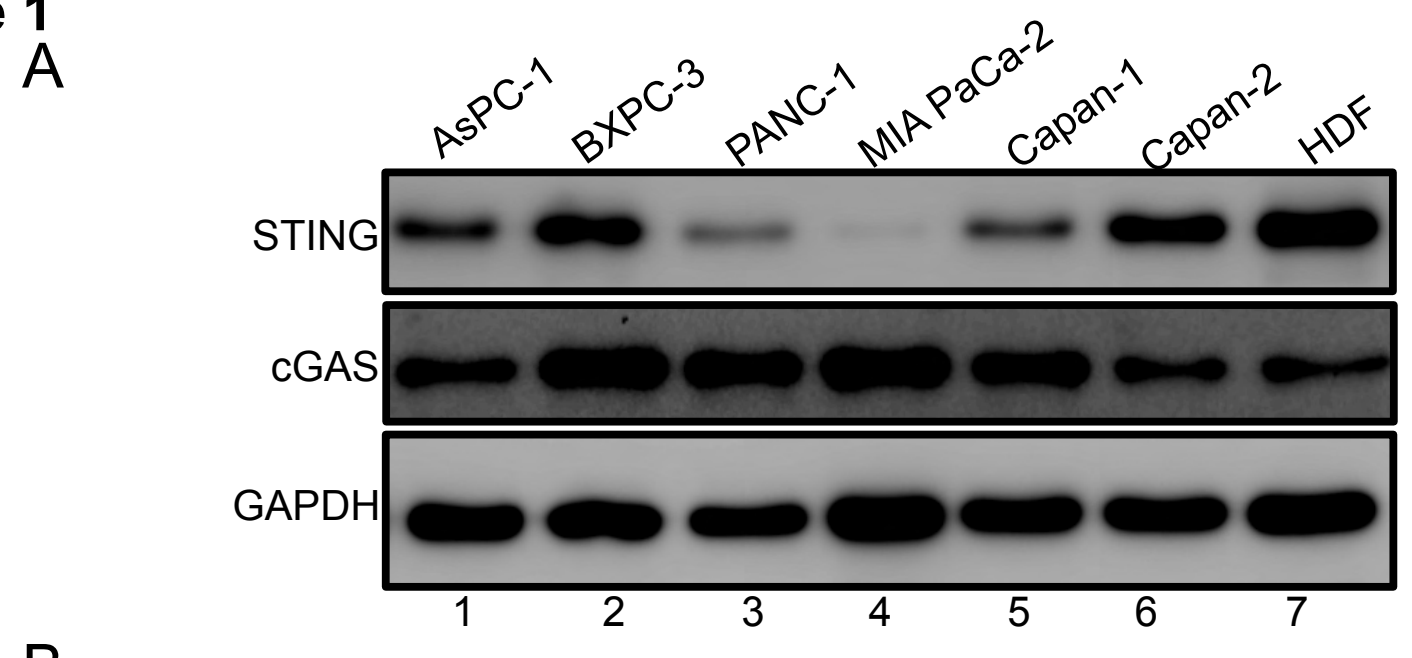

B

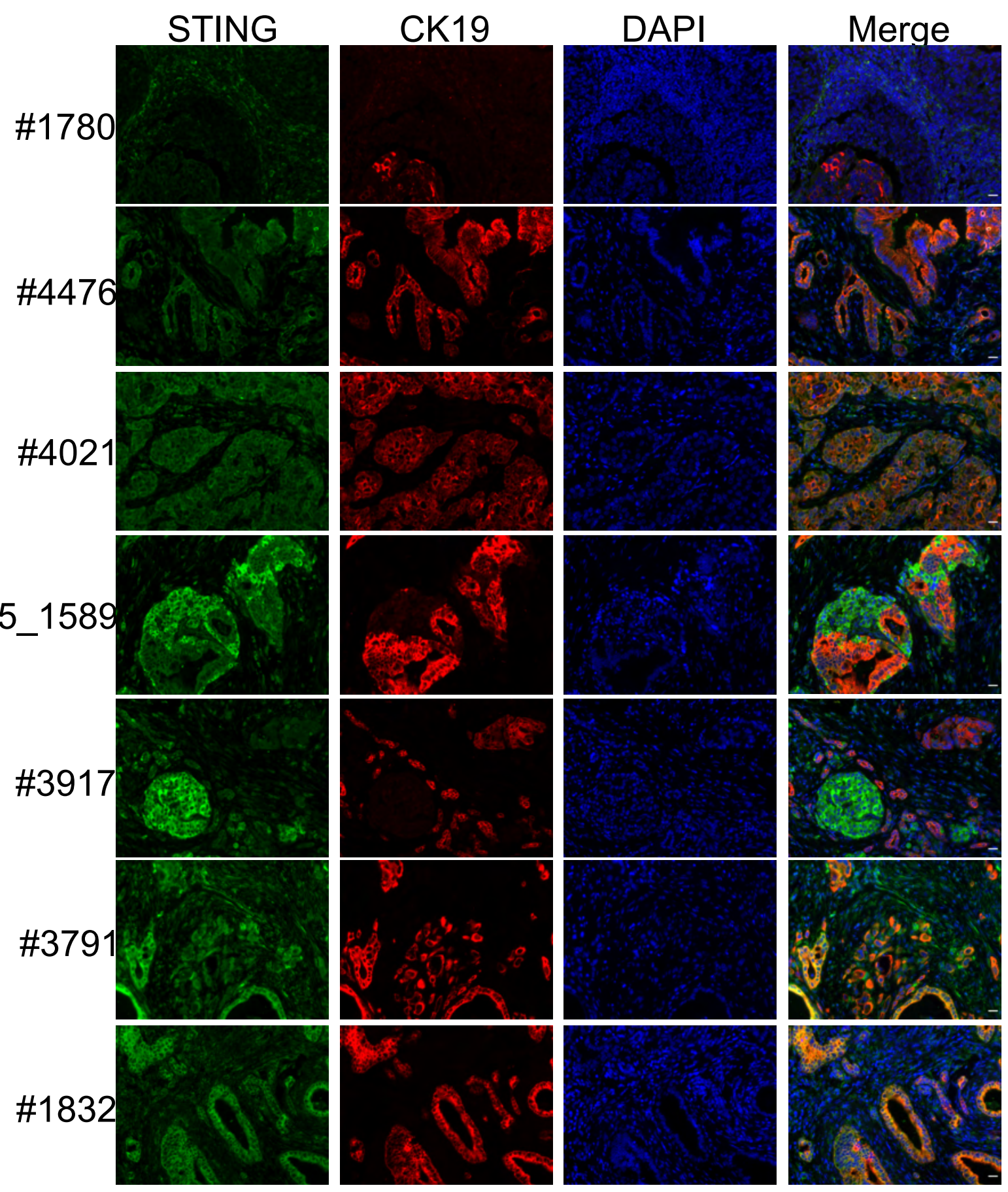




\section{Figure 2}
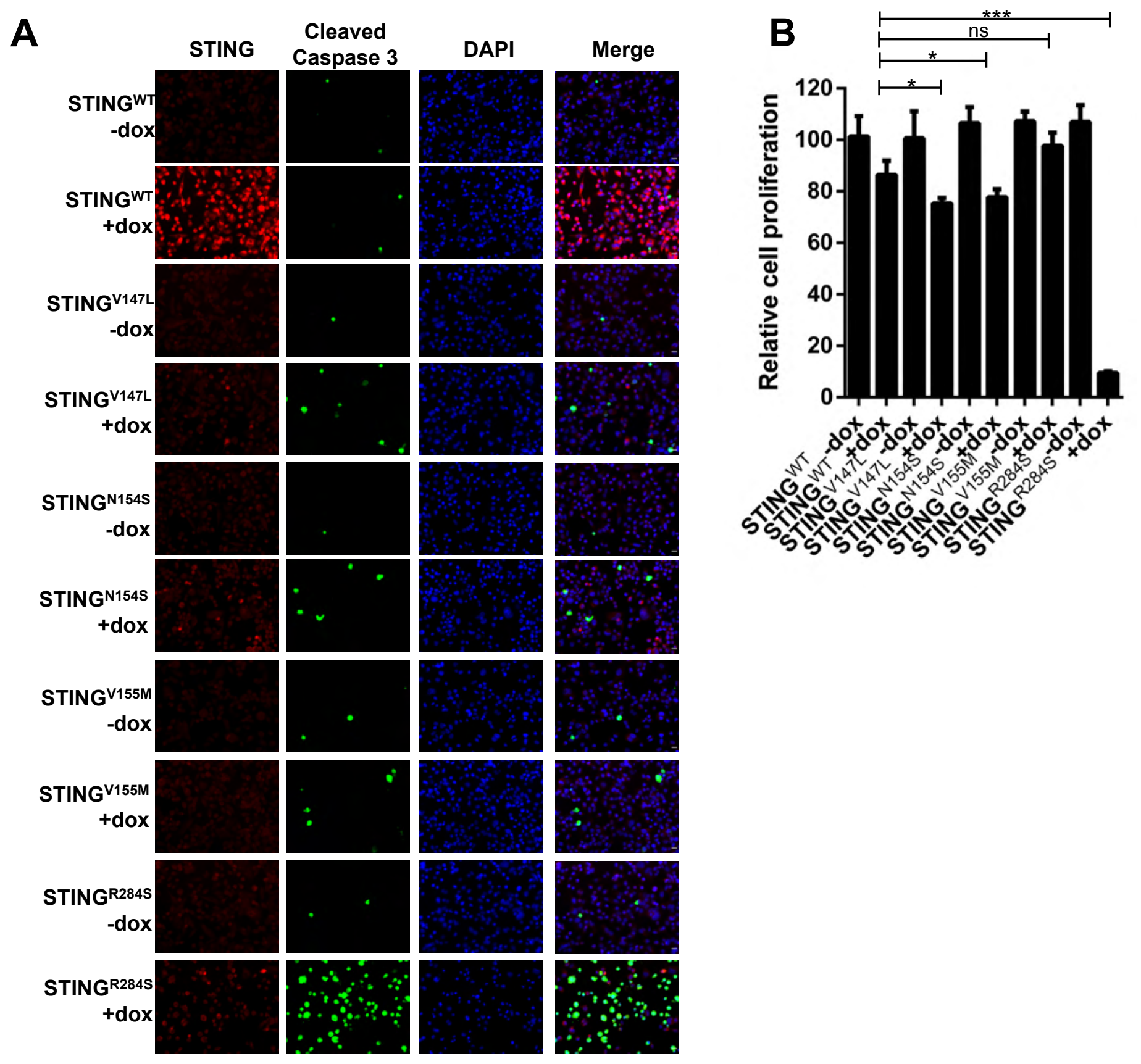


\section{Figure 3}

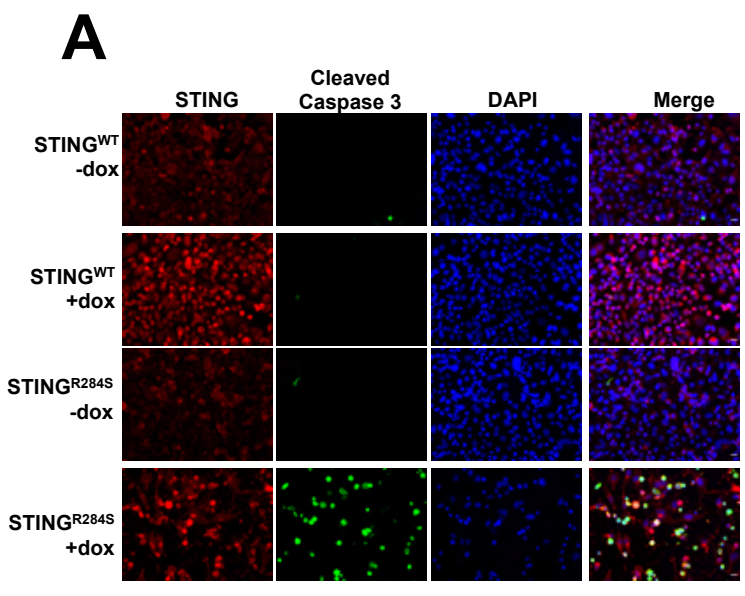

C
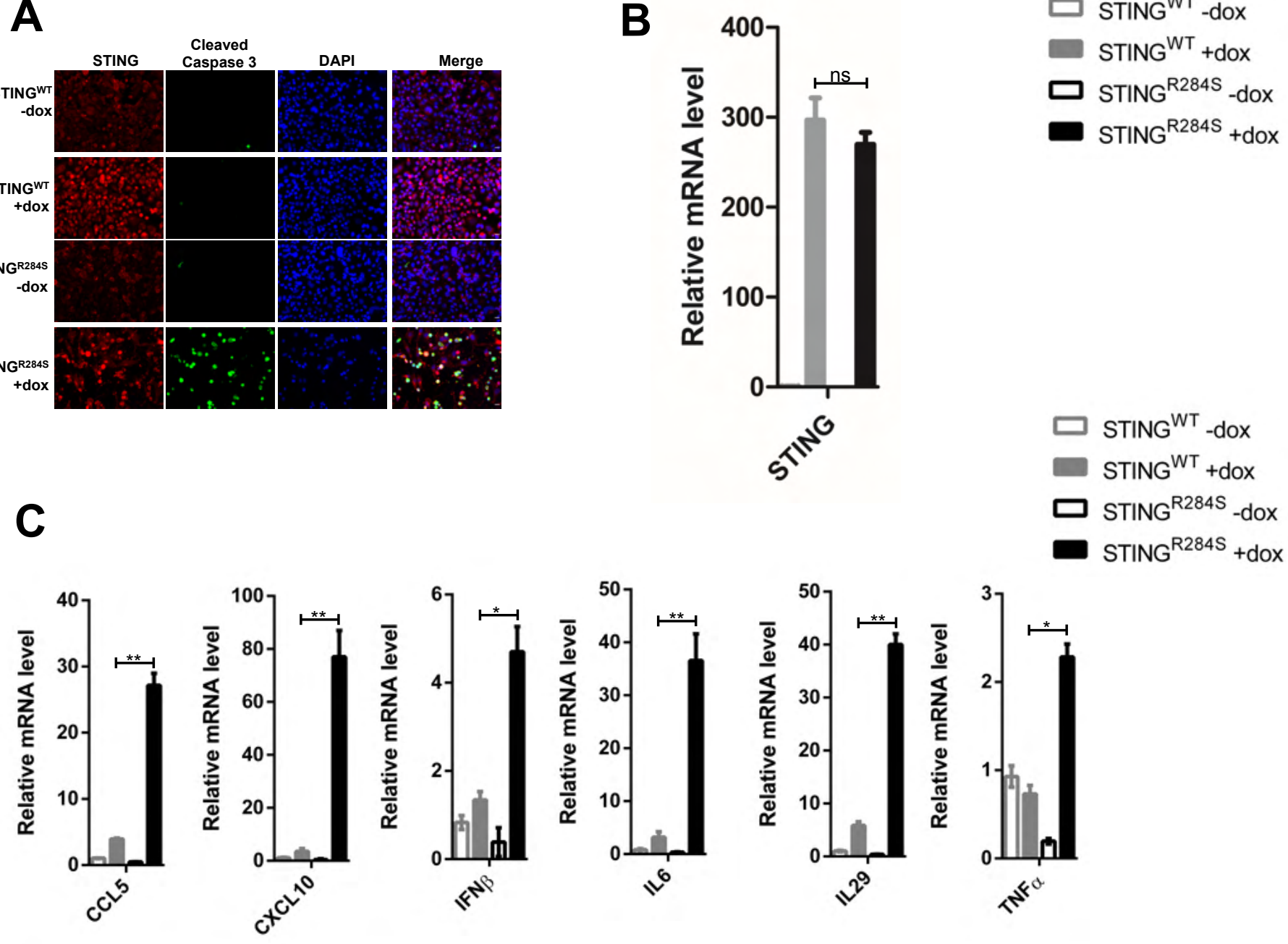

\section{D}

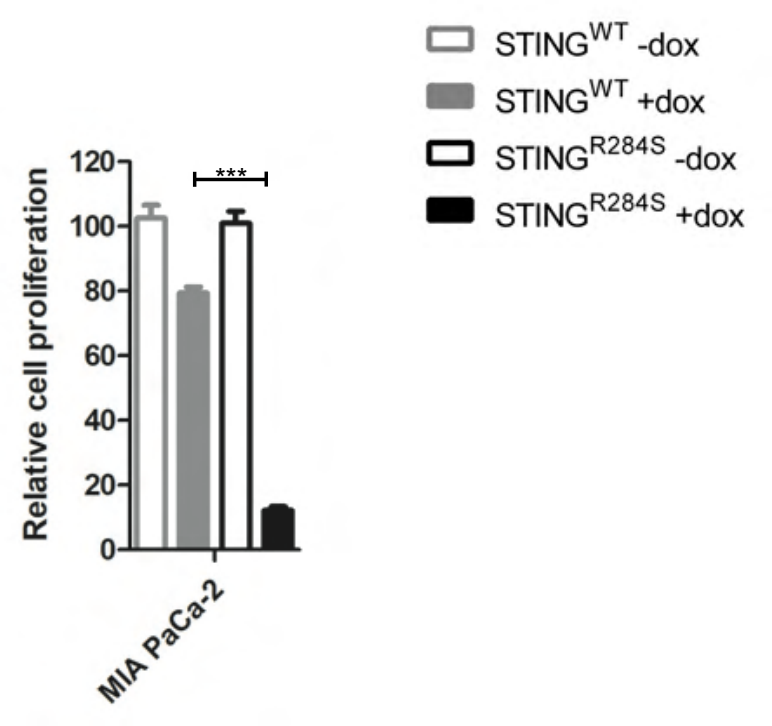




\section{Figure S1}

A

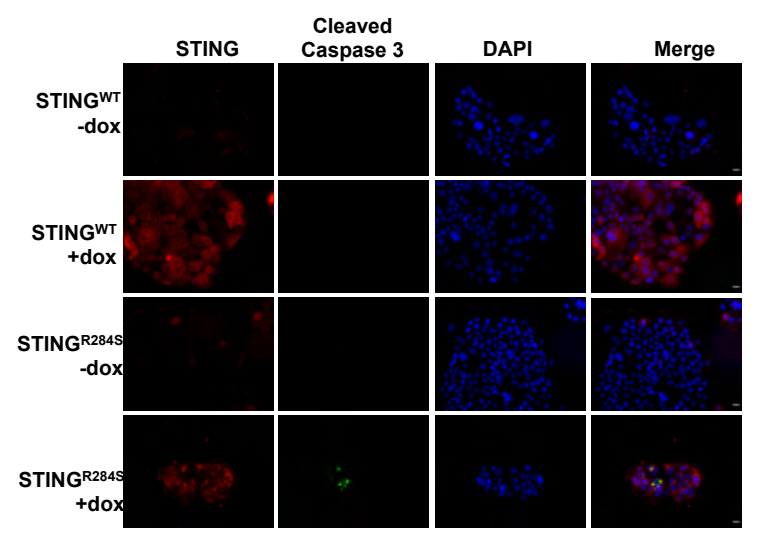

C
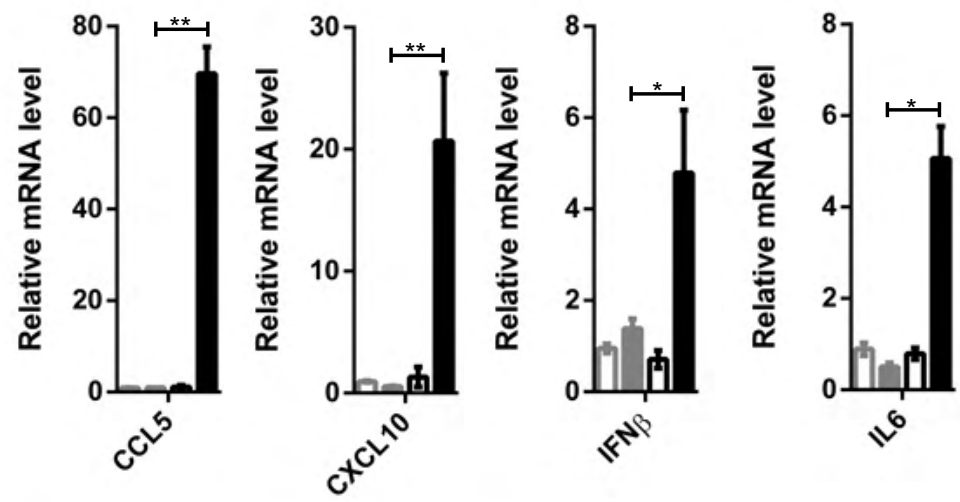

B
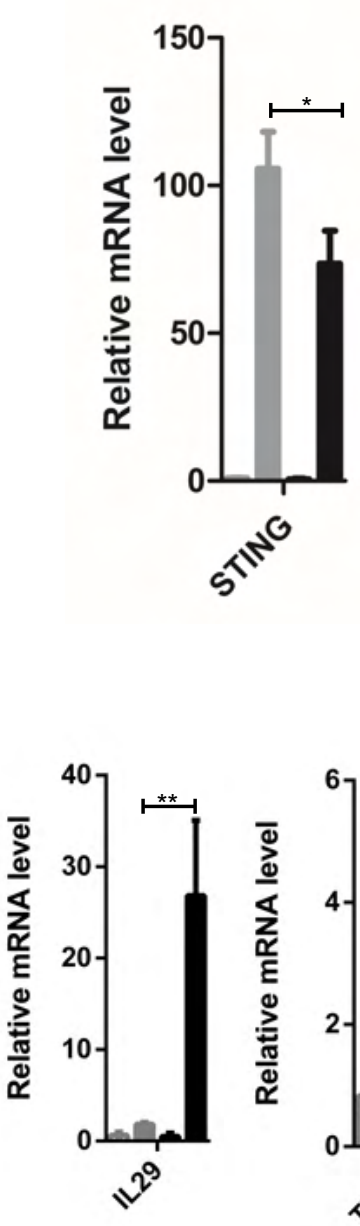

$\square$ STING ${ }^{W T}$-dox

STING ${ }^{W T}+$ dox

$\square$ STING ${ }^{R 284 S}$-dox

STING ${ }^{\mathrm{R} 284 \mathrm{~S}}+\mathrm{dox}$ $\square$ STING ${ }^{W T}$-dox

STING ${ }^{\mathrm{WT}}+$ dox

口 STING ${ }^{R 284 S}$-dox

- STING $^{\mathrm{R} 284 \mathrm{~S}}+\mathrm{dox}$

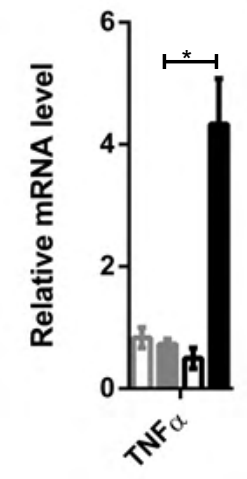

D

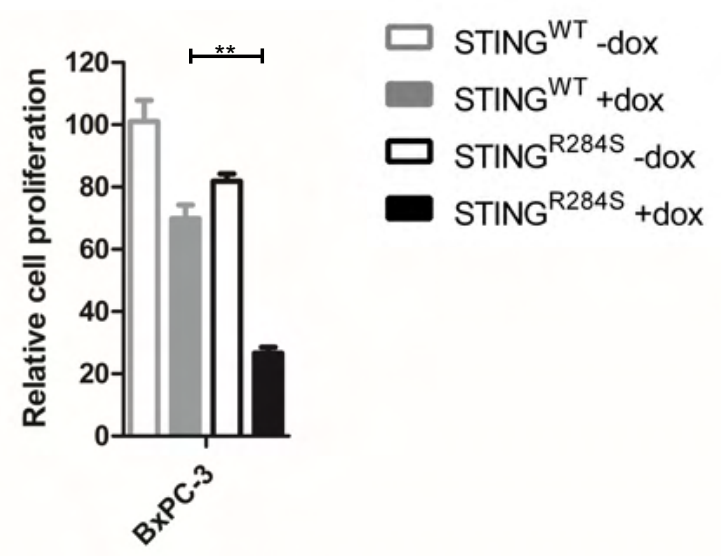




\section{Figure 4}

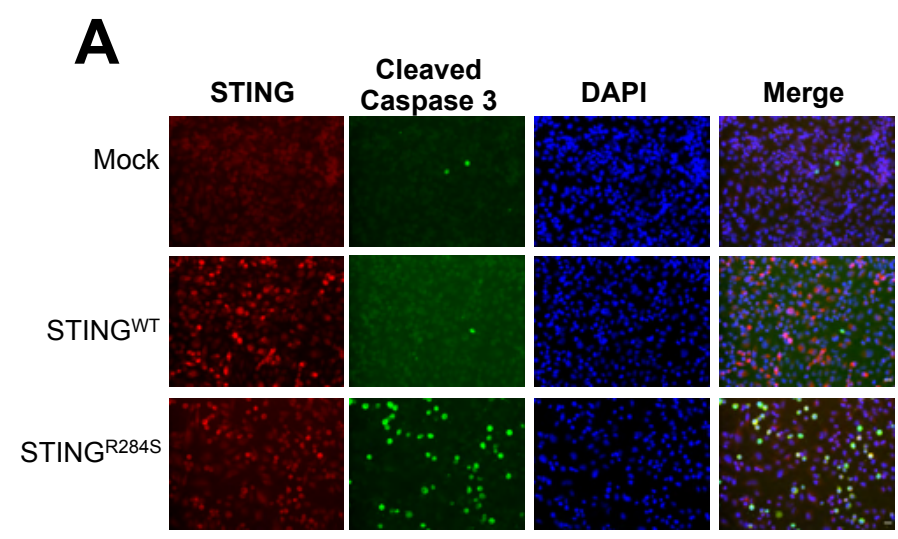

B

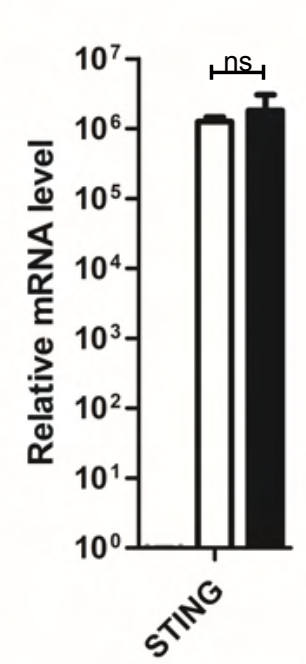

Mock

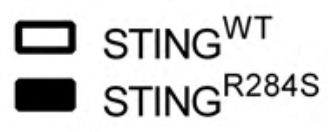

C

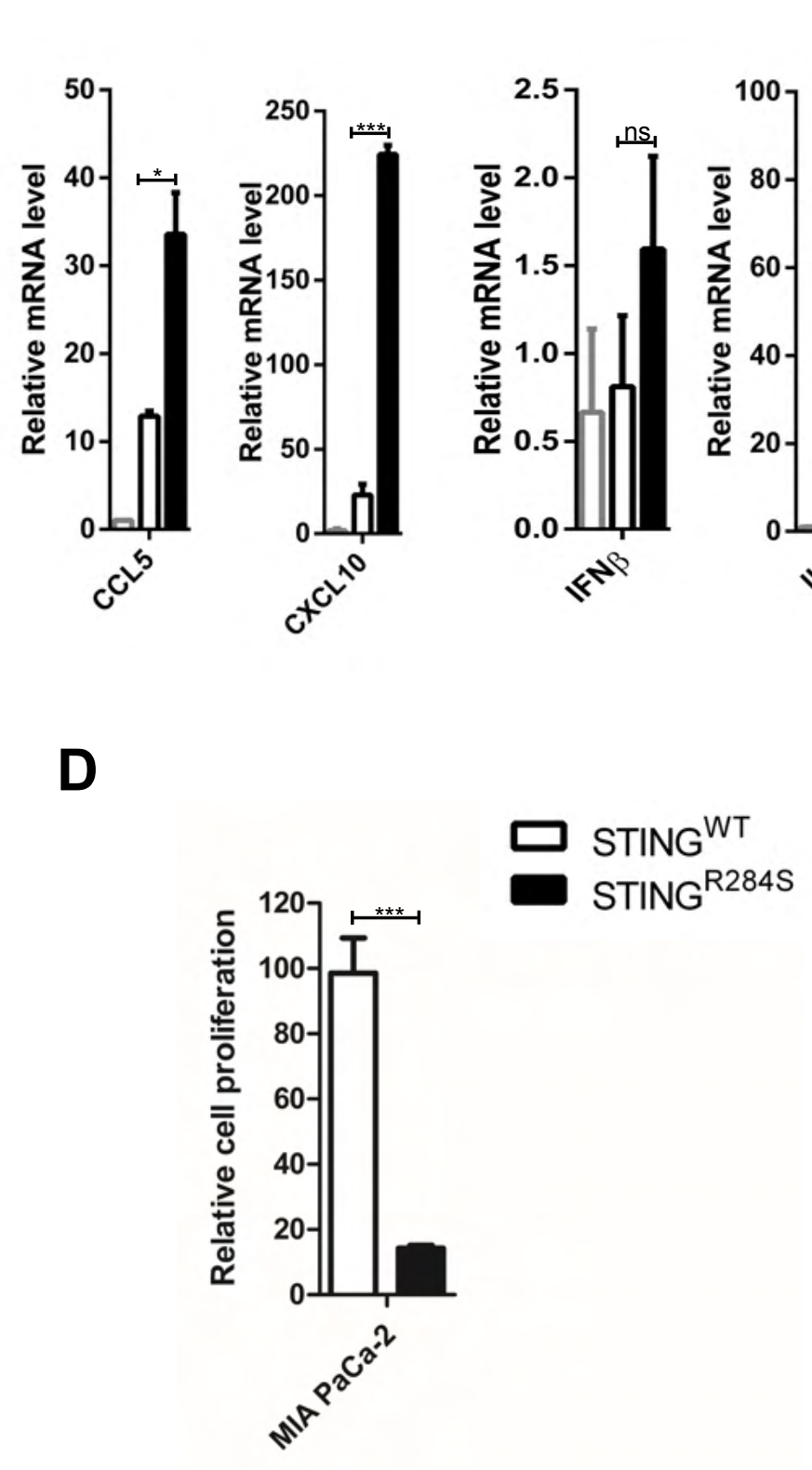




\section{Figure S2}

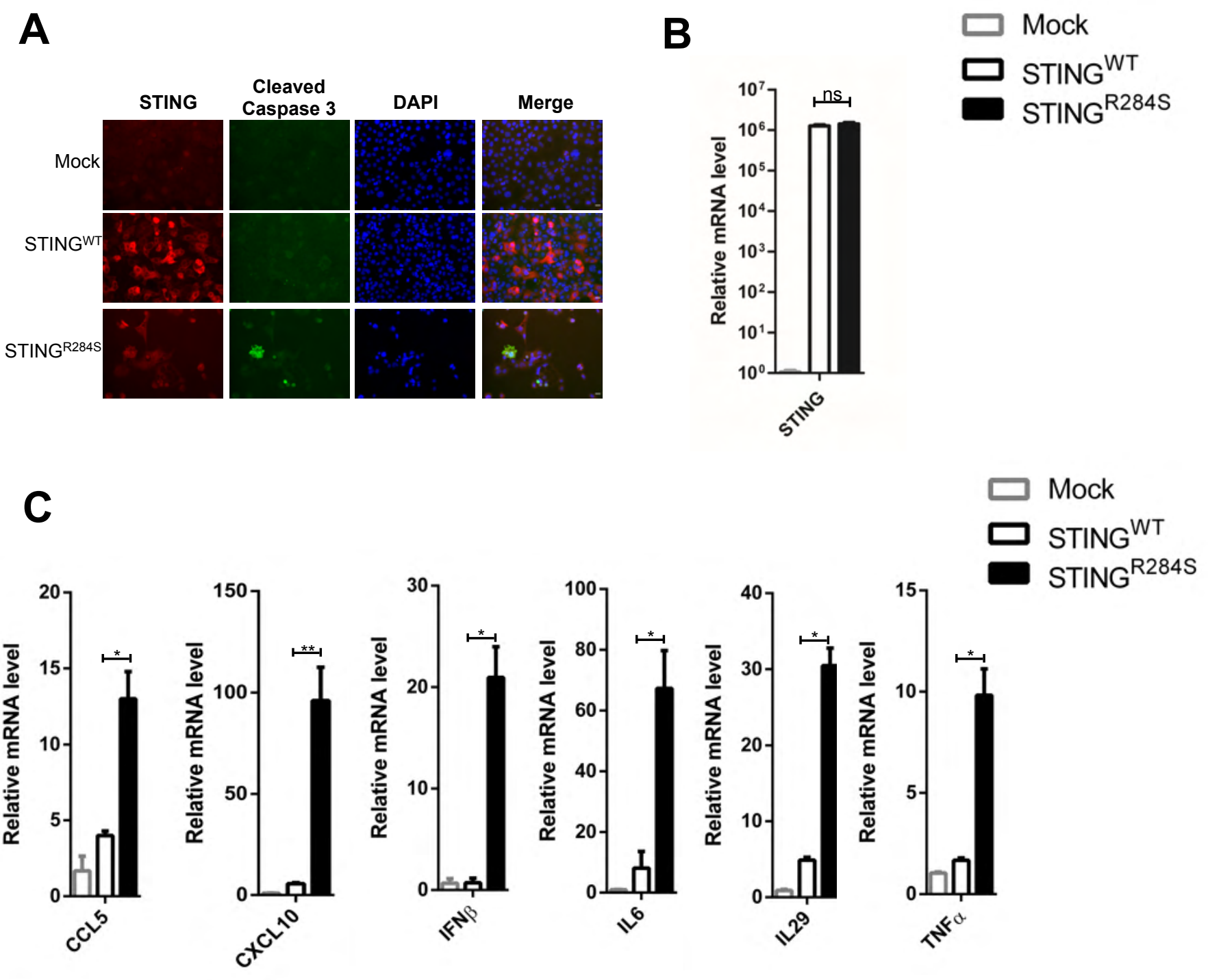

D

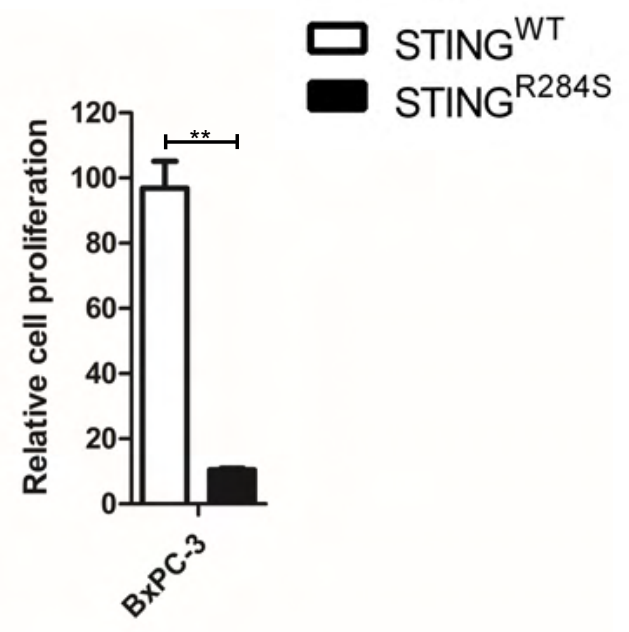




\section{Figure 5}

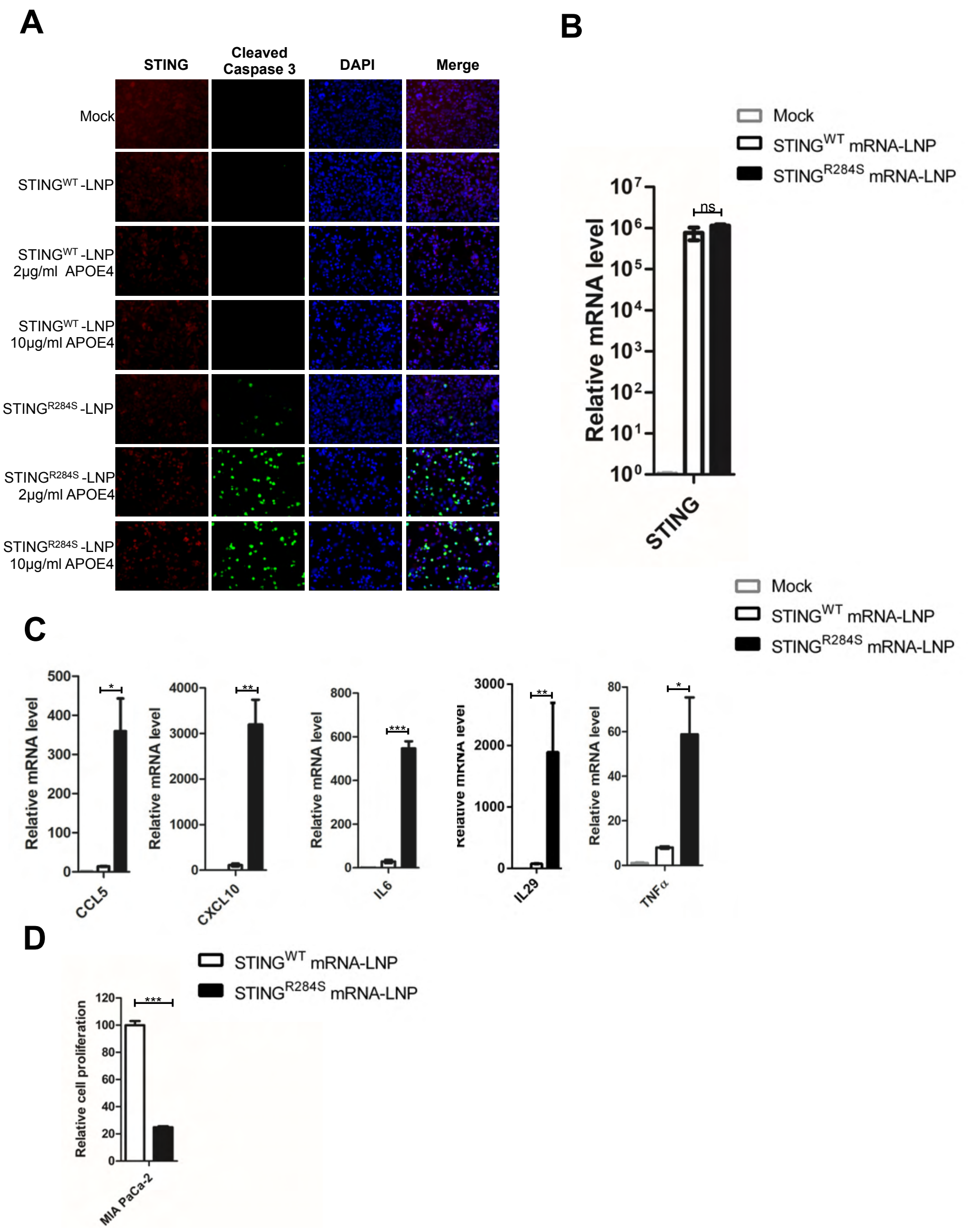




\section{Figure S3}

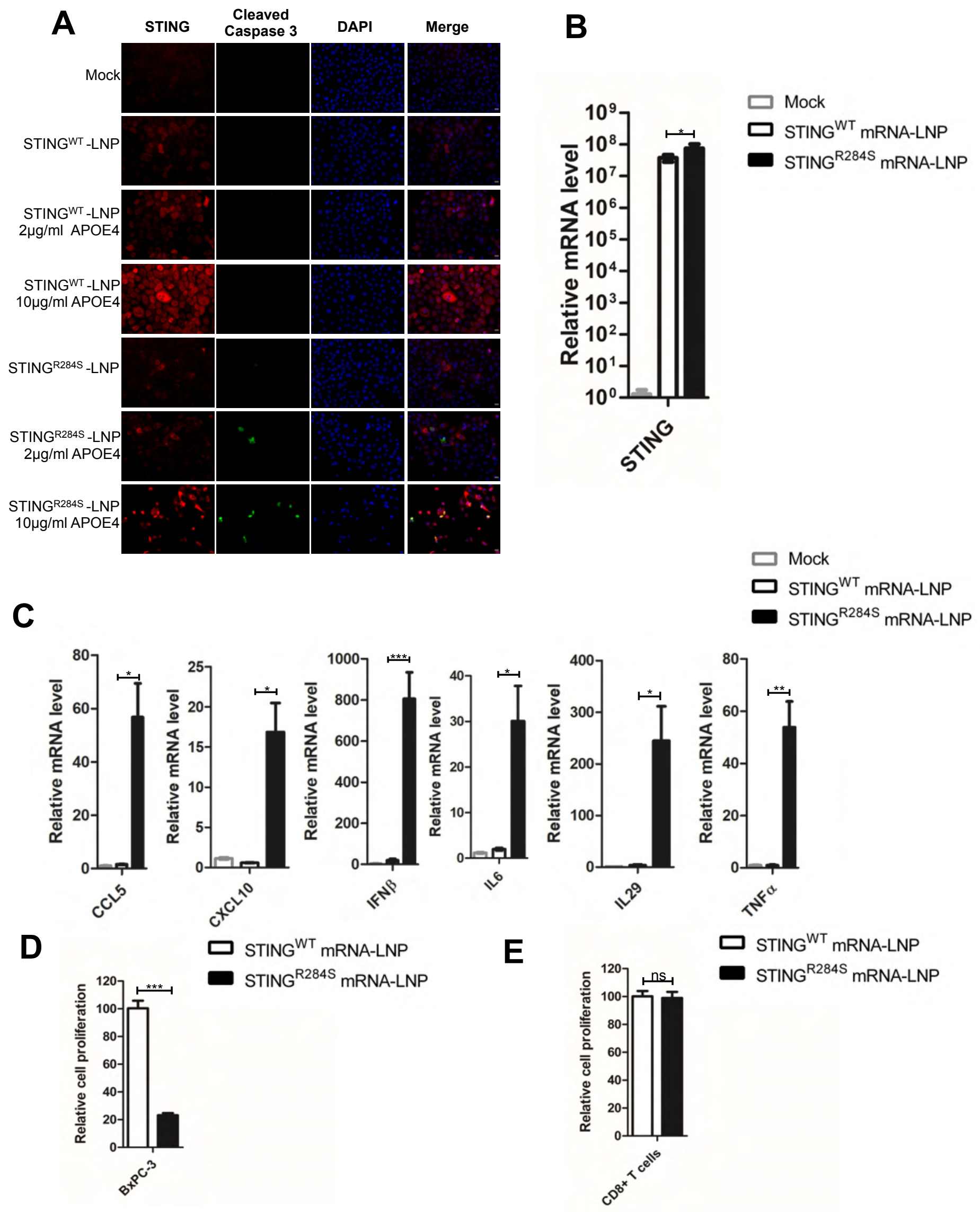




\section{Figure S4}

A
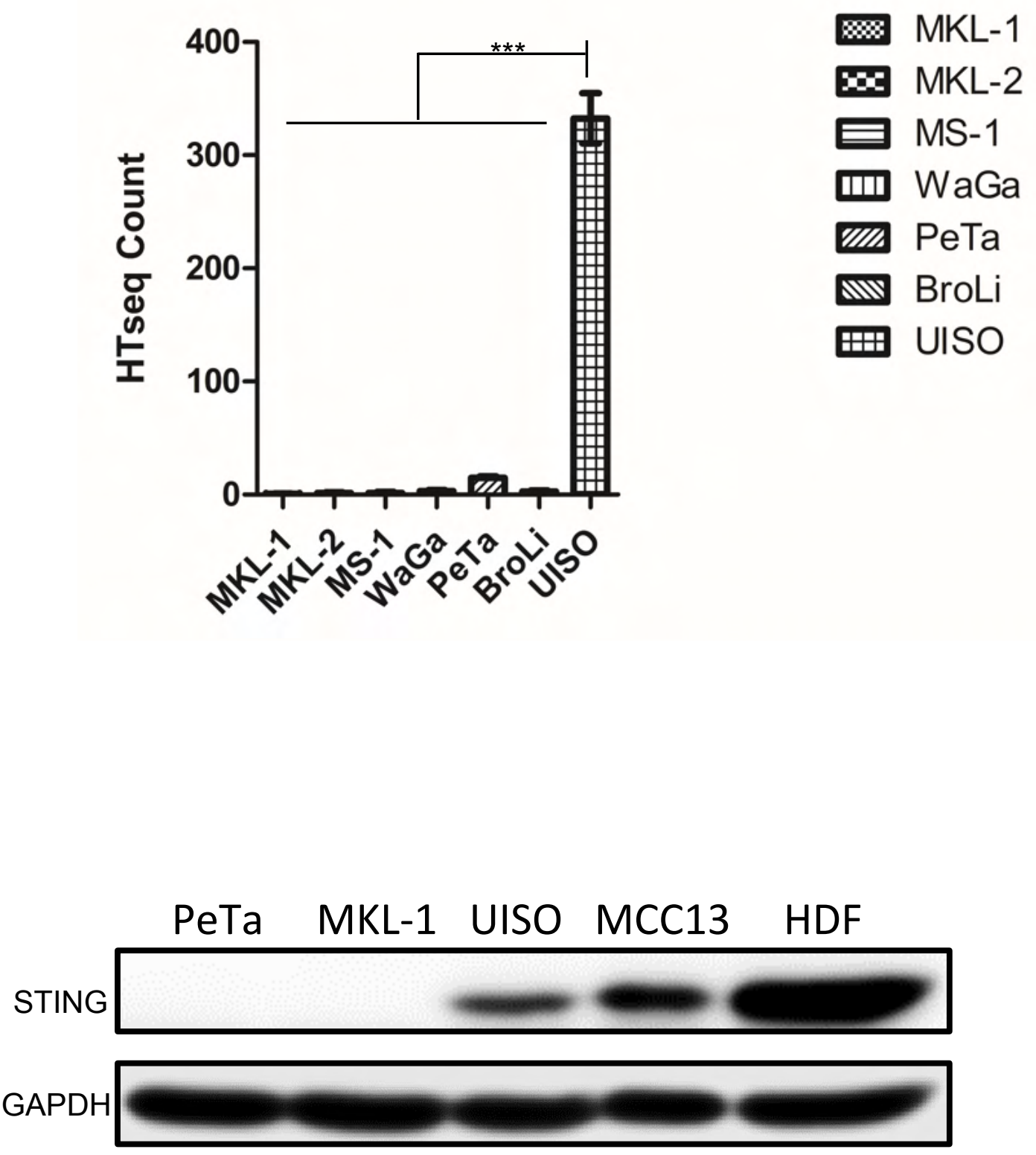


\section{Figure S5}

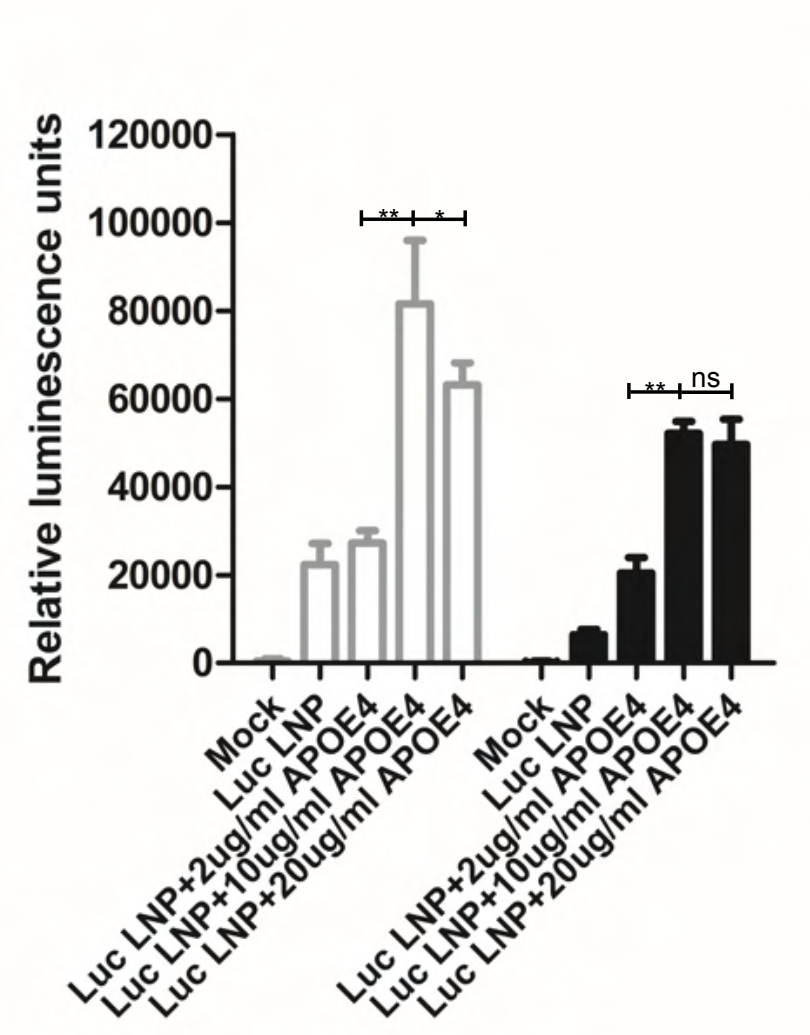

MKL-1

MS-1 


\section{Figure 6}

A

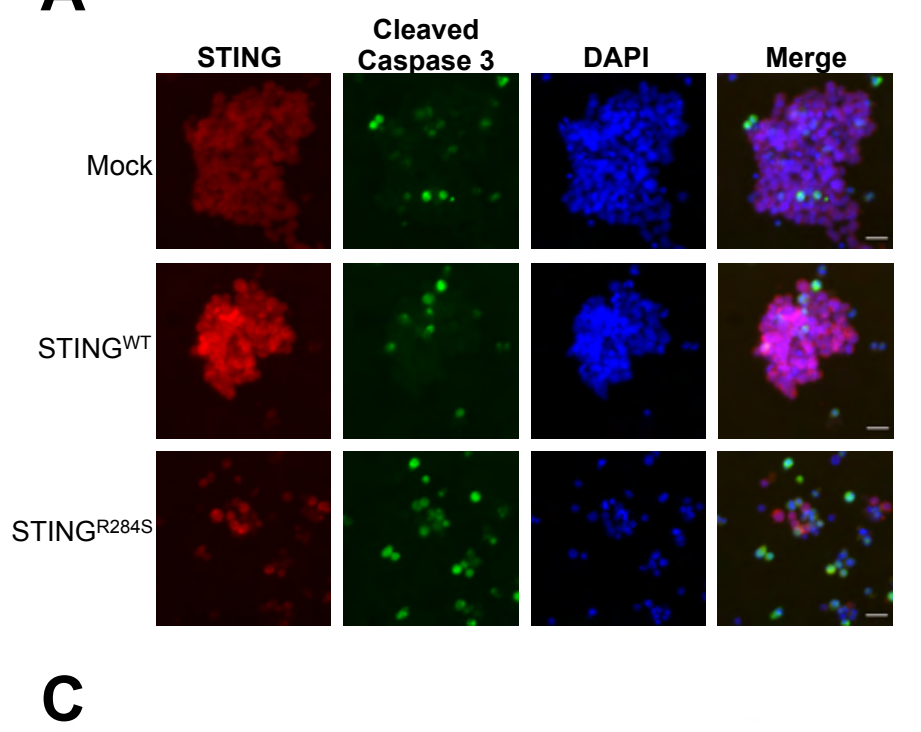

B

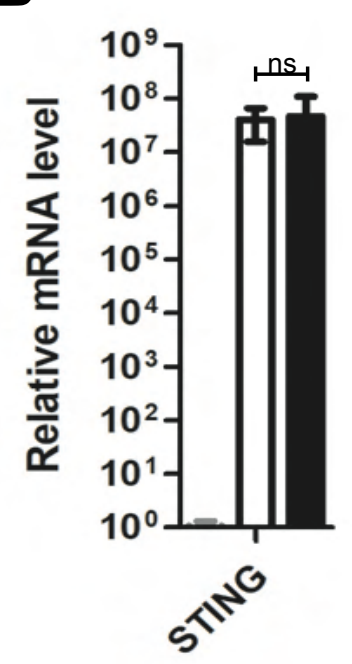

$\square$ Mock

口 STING ${ }^{W T}$ mRNA-LNP

STING ${ }^{R 284 S}$ mRNA-LNP
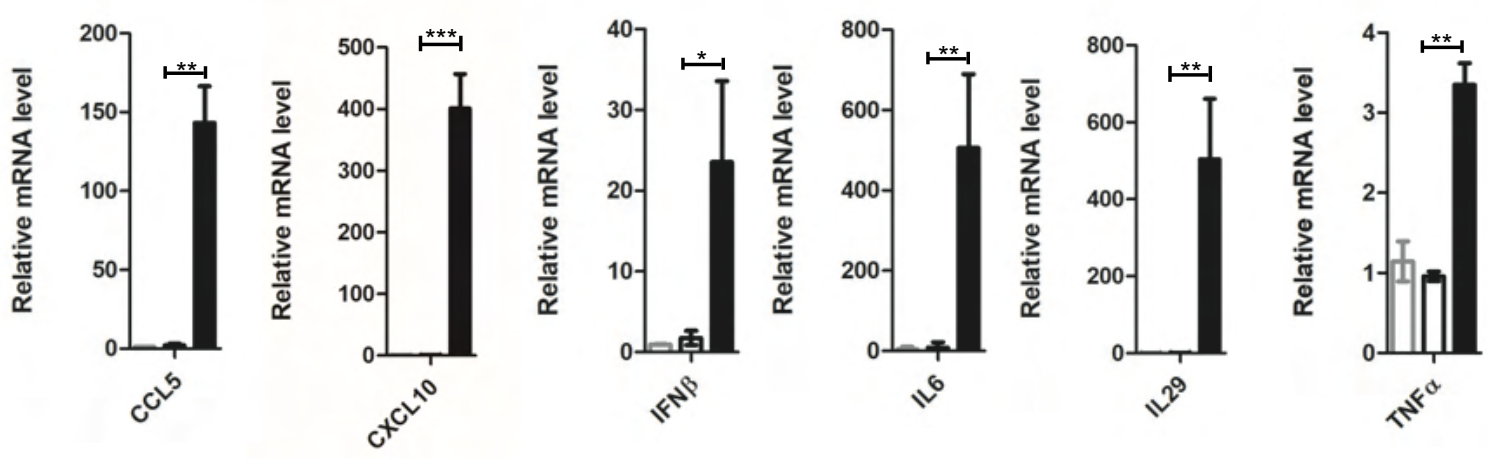

D

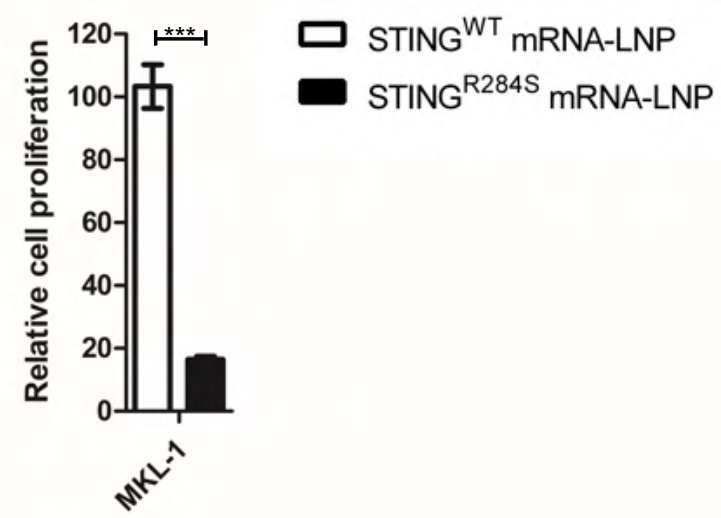




\section{Figure S6}

A

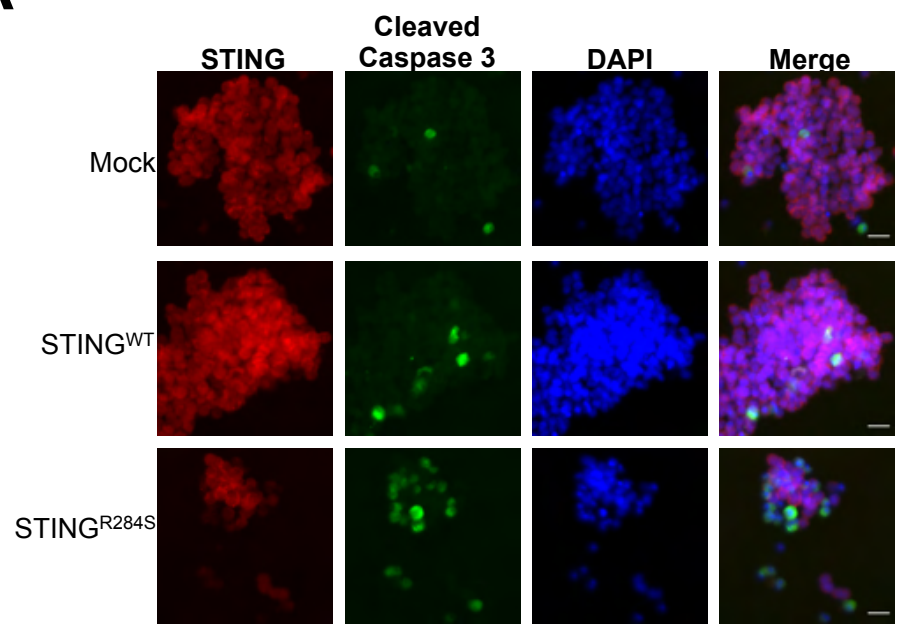

C

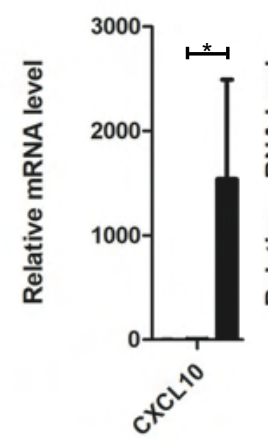

D

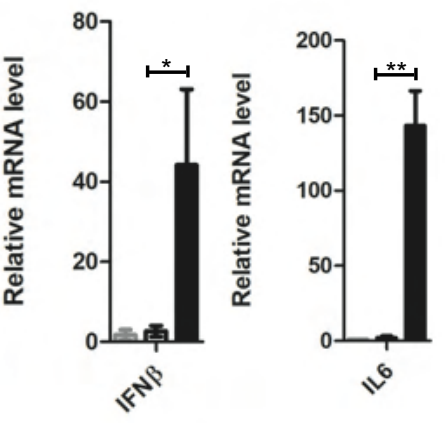

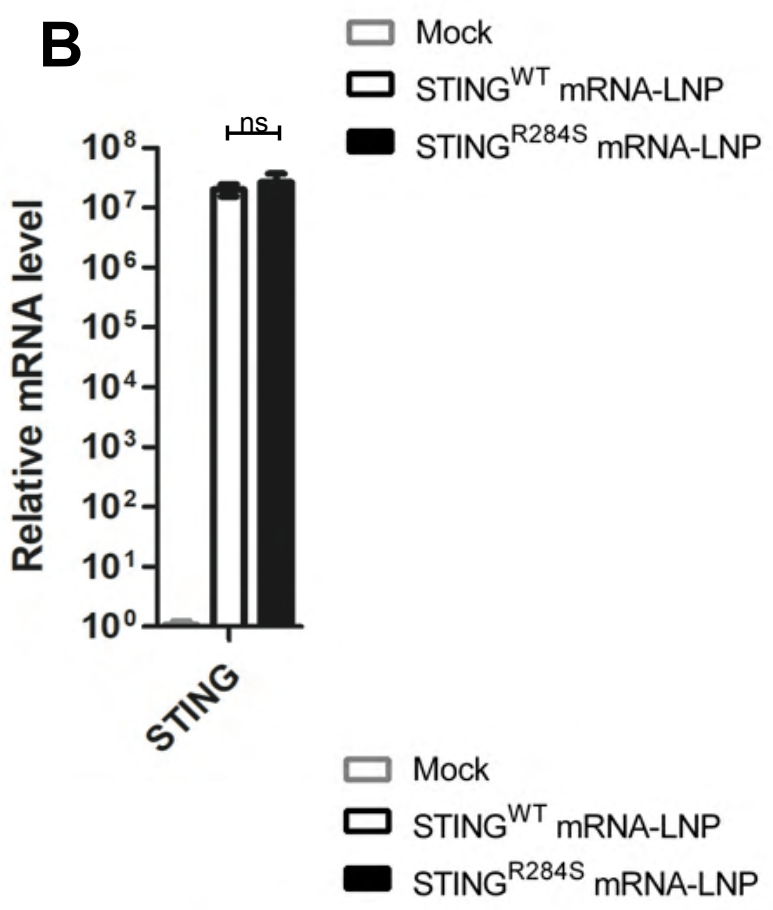

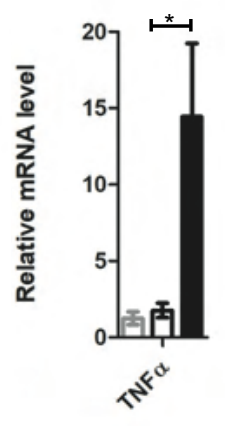

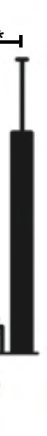
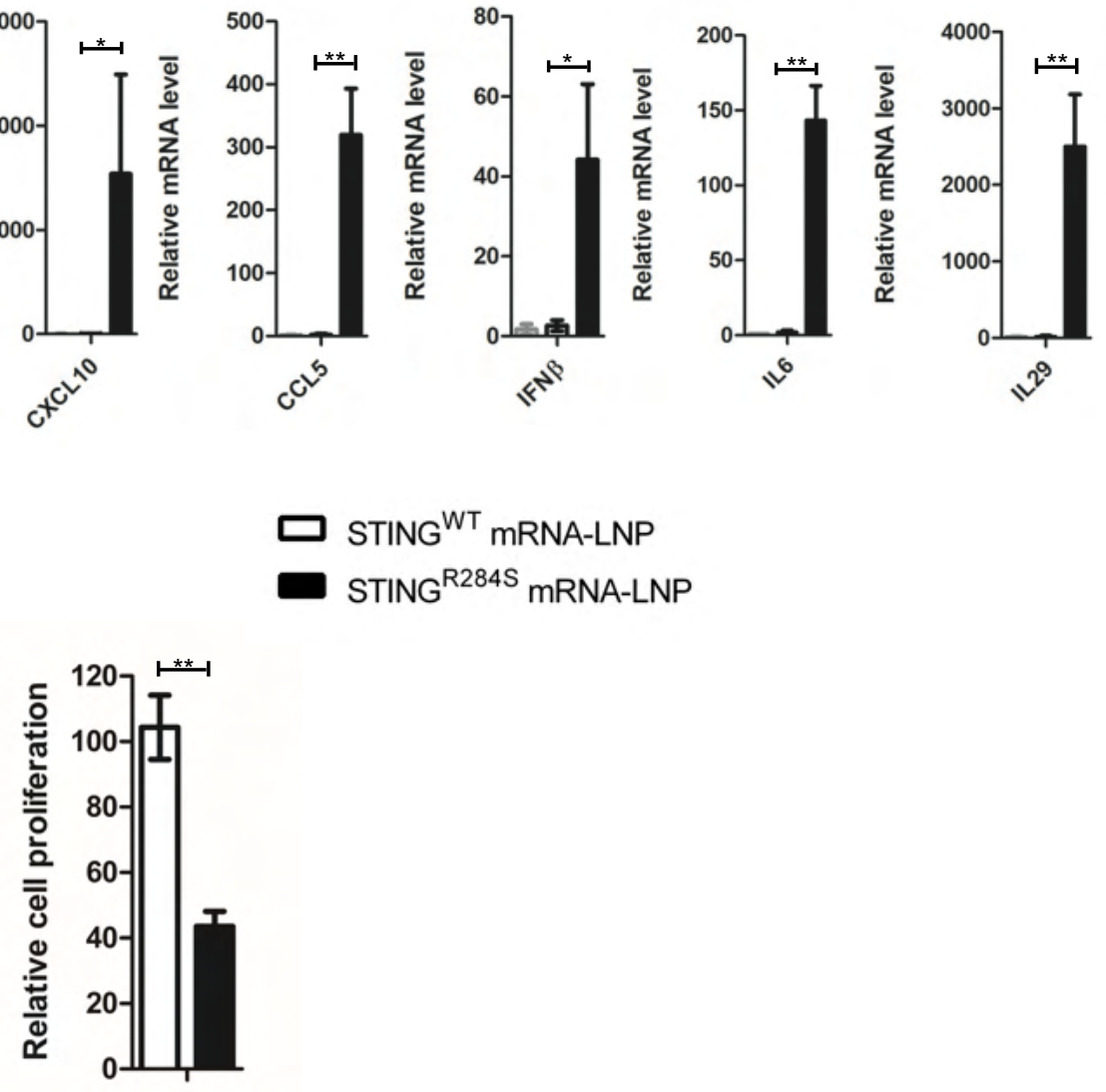